Corresponding Author Email ID: ruairidhjmitchell@gmail.com

\title{
Neoproterozoic evolution and Cambrian reworking of ultrahigh temperature granulites in the Eastern Ghats Province, India
}

\author{
Ruairidh J. Mitchell ${ }^{1,2}$ | Tim E. Johnson ${ }^{1,3}$ | Chris Clark $^{1}$ | Saibal Gupta ${ }^{2}$ | \\ Michael Brown ${ }^{4}$ Simon L. Harley ${ }^{5}$ Richard Taylor $^{6}$
}

\author{
${ }^{1}$ School of Earth and Planetary Sciences, The Institute for Geoscience Research, Curtin \\ University, Perth, WA 6012, Australia \\ ${ }^{2}$ Department of Geology and Geophysics, Indian Institute of Technology, Kharagpur, India \\ ${ }^{3}$ State Key Laboratory for Geological Processes and Mineral Resources and Center for Global \\ Tectonics, School of Earth Sciences, China University of Geosciences, Wuhan 430074, \\ China. \\ ${ }^{4}$ Laboratory for Crustal Petrology, Department of Geology, University of Maryland, College \\ Park, MD 20742-4211, USA \\ ${ }^{5}$ School of Geosciences, University of Edinburgh, Edinburgh, EH9 3FE, UK \\ ${ }^{6}$ Department of Earth Sciences, University of Cambridge, Cambridge, CB2 3EQ, UK
}

Running title: Evolution of UHT granulites in the Eastern Ghats

\begin{abstract}
The timescales and $P-T$ conditions recorded by granulite facies metamorphic rocks permit inferences about the geodynamic regime in which they formed. Two compositionally heterogeneous cordierite-spinel-bearing granulites from Vizianagaram, Eastern Ghats Province (EGP), India, were investigated to provide $P$ - $T$-time constraints using petrography, phase equilibrium modelling, $\mathrm{U}-\mathrm{Pb}$ geochronology, the rare earth element (REE) composition of zircon and monazite, and Ti-in-zircon thermometry. These ultrahigh temperature (UHT) granulites preserve discrete compositional layering in which different inferred peak assemblages are developed, including layers bearing garnet-sillimanite-spinel and others bearing orthopyroxene-sillimanite-spinel. These mineral associations cannot be reproduced by phase equilibrium modelling of whole rock compositions, indicating that the samples became domainal on a scale less than that of a thin section, even at UHT conditions. Calculation of the $P-T$ stability fields for six compositional domains within which the main rock-forming minerals are considered to have attained equilibrium suggests peak metamorphic conditions of $\sim 6.8-8.3 \mathrm{kbar}$ at $\sim 1000^{\circ} \mathrm{C}$. In most of these domains, the subsequent evolution resulted in the growth of cordierite and final crystallization of melt at an elevated (residual) $\mathrm{H}_{2} \mathrm{O}$-undersaturated solidus, consistent with $<1$ kbar of decompression. Concordant U-Pb ages obtained by SHRIMP from zircon (spread 1050-800Ma) and monazite (spread 950-800Ma) demonstrate that crystallization of these minerals occurred during an interval of $c$. $250 \mathrm{Ma}$. By combining LA-ICPMS U-Pb zircon ages with Ti-inzircon temperatures from the same analysis sites, we show that the crust may have remained

This article has been accepted for publication and undergone full peer review but has not been through the copyediting, typesetting, pagination and proofreading process, which may lead to differences between this version and the Version of Record. Please cite this article as doi: $10.1111 /$ jmg. 12451

This article is protected by copyright. All rights reserved.
\end{abstract}


above $900^{\circ} \mathrm{C}$ for a minimum of $c .120$ Ma between $c .1000$ and $c .880 \mathrm{Ma}$. Overall, the results suggest that, in the interval 1050 to $800 \mathrm{Ma}$, the evolution of the Vizianagaram granulites culminated with UHT conditions from $c .1000 \mathrm{Ma}$ to $c .880 \mathrm{Ma}$, associated with minor decompression, before further zircon crystallization at $c$. 880-800 Ma during cooling to the solidus. However, these rocks are adjacent to the Paderu-Anantagiri-Salur crustal block to the NW that experienced counterclockwise $P-T-t$ paths, and records similar UHT peak metamorphic conditions $\left(7-8 \mathrm{kbar}, \sim 950^{\circ} \mathrm{C}\right)$ followed by near-isobaric cooling, and has a similar chronology during the Neoproterozoic. The limited decompression inferred at Vizianagaram may be explained by partial exhumation due to thrusting of this crustal block over the adjacent Paderu-Anantagiri-Salur crustal block. The residual granulites in both blocks have high concentrations of heat producing elements and likely remained hot at midcrustal depths throughout a period of relative tectonic quiescence in the interval 800-550 Ma. During the Cambrian Period the EGP was located in the hinterland of the Denman-PinjarraPrydz orogen. A later concordant population of zircon dated at $511 \pm 6$ Ma records crystallization at temperatures of $\sim 810^{\circ} \mathrm{C}$. This age may record a low-degree of melting due to limited influx of fluid into hot, weak crust in response to convergence of the Crohn craton with a composite orogenic hinterland comprising the Rayner terrane, Eastern Ghats Province and cratonic India.

\section{KEYWORDS}

Eastern Ghats Province, phase equilibrium modelling, Ti-in-zircon thermometry, $\mathrm{U}-\mathrm{Pb}$ geochronology, UHT metamorphism

\section{1 | INTRODUCTION}

Exhumed granulite facies metamorphic rocks are witnesses to the evolving thermal and rheological conditions in the mid-to-lower crust during orogenesis (Brown \& Johnson, 2018; Harley, 1989, 2008; Kelsey \& Hand, 2015). The widespread occurrence of high temperatures in the deep crust throughout Earth's history is inferred from the presence of granulites with metamorphic ages ranging from the Archean to the present day (Brown, 2007a; Harley, 1998; Kelsey, 2008; Kelsey \& Hand, 2015). The suggested duration of high and ultrahigh temperature metamorphic events vary from $<$ or $<<20 \mathrm{Ma}$ (Dragovic, Guevara, Caddick, Baxter, \& Kylander-Clark, 2016; Galli et al., 2011; Pownall, 2015) to in excess of $100 \mathrm{Ma}$ (Blereau et al., 2017; Harley, 2016; Holder, Hacker, Horton, \& Rakotondrazafy, 2018; Korhonen, Clark, Brown, Bhattacharya, \& Taylor, 2013).

Granulites form across a range of apparent thermal gradients to reach high and ultrahigh temperatures (UHT, at $>900^{\circ} \mathrm{C}$ ), conditions under which widespread partial melting, melt migration and melt loss are inevitable for almost all crustal protoliths (e.g. Brown, 2013; Johnson, White, \& Powell, 2008; Rushmer, 1991; White, Powell, Holland, Johnson, \& Green, 2014). In addition, granulites may record a range of retrograde $P-T$ paths associated with cooling rates that vary from fast to slow (Harley, 2016; Kelsey \& Hand, 2015). Metamorphic conditions recovered from peak metamorphic mineral assemblages typically yield apparent thermal gradients ranging from $\sim 77.5^{\circ} \mathrm{C} / \mathrm{kbar}$ to $>150{ }^{\circ} \mathrm{C} / \mathrm{kbar}$ (Brown \& Johnson, 2018). Several 1D thermal models predict that UHT conditions may be sustained for $60 \mathrm{Ma}$ or more at crustal depths of $\sim 20-50 \mathrm{~km}$, if there was a favourable combination of high mantle heat flow, elevated radiogenic heat production from heat producing elements (HPE), net removal of melt, and low erosion rates (Clark, Fitzsimons, Healy, \& Harley, 2011; Horton, Hacker, Kylander-Clark, Holder, \& Jöns, 2016).

This article is protected by copyright. All rights reserved. 
Many granulite terranes are temporally linked to supercontinent assembly (Brown, 2007a, 2007b; Brown \& Johnson, 2018; Clark et al., 2015; Sizova, Gerya, \& Brown, 2014). Extension in backarc regions within accretionary orogens may result in high advectivelydriven thermal gradients, leading to UHT metamorphism as a precursor to thickening and formation of mobile belts during collision (Brown, 2007b) in rocks containing high concentrations of HPE (Clark et al., 2011). This hypothesis may provide a robust explanation for granulite facies metamorphism in modern backarcs (Currie \& Hyndman, 2006; Hyndman, 2015; Hyndman \& Currie, 2011). Alternatively, granulite facies metamorphism may occur in the deep crust of thickened orogenic plateaux (Clark et al., 2015; Harley, 2016; Harley, 1989; Jamieson \& Beaumont, 2011; Jamieson, Beaumont, Warren, \& Nguyen, 2010), particularly where radiogenic heat production and low erosion rates may be sustained for $>60 \mathrm{Ma}$ (Clark et al., 2011). Examples of such settings include the modern Tibetan plateau (Hacker et al., 2000; McKenzie \& Priestley, 2008), where granulite facies metamorphism is still occurring (Hacker, Ritzwoller, \& Xie, 2014), and the East African Orogen (Collins, Fitzsimons, Hulscher, \& Razakamanana, 2003; Fritz et al., 2013), in which late Neoproterozoic and early Palaeozoic metamorphism lasted for up to $100 \mathrm{Ma}$ (Boger et al., 2015; Clark et al., 2015; Collins, Clark, \& Plavsa, 2014; Plavsa, Collins, Foden, \& Clark, 2015).

In order to evaluate the tectonic evolution of a terrane with similarly long lived granulite facies conditions, we present further $P-T$-time constraints; data from metapelitic rocks from Vizianagaram, Eastern Ghats Province (EGP), India (Figure 1). We use petrographic observations combined with phase equilibrium modelling, $\mathrm{U}-\mathrm{Pb}$ geochronology of zircon and monazite, coupled with the REE concentrations of zircon, and Ti-in-zircon thermometry to suggest that these rocks experienced long-lived UHT conditions in the interval 1000-880 Ma, associated with decompression of <1 kbar. These rocks may have remained melt bearing for a total of $c$. 250 million years in the interval 1050-800 Ma. Further, there is evidence for suprasolidus neocrystallization of zircon at temperatures of $\sim 810^{\circ} \mathrm{C}$ at c. $510 \mathrm{Ma}$. Our results from Vizianagaram contrast with published results from the adjacent Paderu-Anantagiri-Salur crustal block to the NW, which experienced counterclockwise $P-T-t$ paths at UHT conditions followed by near-isobaric cooling (Das, Bose, Karmakar, Dunkley, \& Dasgupta, 2011; Korhonen, Brown, Clark, \& Bhattacharya, 2013; Korhonen, Clark, et al., 2013; Korhonen, Clark, Brown, \& Taylor, 2014; Korhonen, Saw, Clark, Brown, \& Bhattacharya, 2011). This contrast suggests a tectonic model in which two crustal blocks were juxtaposed by thrusting.

\section{2 | REGIONAL GEOLOGY}

The Eastern Ghats Mobile Belt is a polymetamorphic terrane located in the east of the Indian peninsula (Figure 1). The rocks preserve a varied and complex history spanning the period from the late Paleoproterozoic to the early Palaeozoic (Dasgupta, Bose, \& Das, 2013; Kelsey et al., 2017; Rickers, Mezger, \& Raith, 2001; T. Sarkar \& Schenk, 2016; Simmat \& Raith, 2008; Upadhyay, Gerdes, \& Raith, 2009). Discrete crustal blocks (terranes) bounded by large-scale shear zone systems have previously been invoked based on the isotopic, metamorphic and lithological characteristics of the rocks (Rickers, Mezger, et al., 2001). One such terrane, the Eastern Ghats Province (EGP; Figure 1), lies between the Godaravi rift to the south, the Kerajang shear zone to the north and the Sileru shear zone system to the west (Dobmeier \& Raith, 2003).

Multiple localities within the EGP preserve evidence for UHT conditions (Das et al., 2011; Korhonen, Brown, et al., 2013; Korhonen, Clark, et al., 2013; Korhonen et al., 2014; Korhonen et al., 2011; Prakash et al., 2015), suggesting that UHT metamorphism was regional in extent. The $P-T$ evolution of rocks within the EGP has been constrained using a variety of methods at different localities. Phase equilibrium studies from various localities 
constrain peak conditions to $>950^{\circ} \mathrm{C}$ and $\sim 8 \mathrm{kbar}$ followed by near-isobaric cooling (Korhonen, Brown, et al., 2013; Korhonen et al., 2011). In addition, high Al-Mg granulites at Anantagiri are inferred to record peak metamorphic temperatures that exceeded $1000^{\circ} \mathrm{C}$ (Korhonen et al., 2014).

The duration of granulite facies conditions in the EGP has been estimated from $\mathrm{U}-\mathrm{Pb}$ zircon and monazite geochronology at multiple localities (Korhonen, Brown, Clark, Foden, \& Taylor, 2015; Korhonen, Clark, et al., 2013). Korhonen, Clark, et al. (2013) reported protracted growth of metamorphic zircon throughout the EGP over durations of up to $300 \mathrm{Ma}$ between $c .1100$ and $c .800 \mathrm{Ma}$. Their samples yielded discrete clusters of concordant zircon and monazite ages within this broader temporal range, implying partial melt crystallization above different elevated $\left(\mathrm{H}_{2} \mathrm{O}\right.$-undersaturated) solidii following some drainage of melt. Nearconcordant ages of 613 and $566 \mathrm{Ma}$ may record new zircon growth or else be related to $\mathrm{Pb}$ loss from older zircon due to lower temperature fluid-mediated processes (Korhonen, Clark, et al., 2013). Although there are no $P-T$ constraints linked to these Pan African ages, to the west Mahato and Bhattacharya (2010) reported $P-T$ conditions of $6.5 \pm 1.5 \mathrm{kbar}$ and $730 \pm 30$ ${ }^{\circ} \mathrm{C}$ related to a Pan African metamorphic overprint which may have been developed close to the Eastern Ghats Frontal Thrust at c. 525-510 Ma (Chatterjee, Das, Bose, Ganguly \& Hidaka, 2017). Additionally c. $700 \mathrm{Ma}$ zircon U-Pb and 724-698 Ma titanite U-Pb ages (Nanda, Gupta \& Hacker, 2018) have been recovered close to the Sileru Shear Zone (Figure $1)$.

The EGP samples analysed in this study are garnet-cordierite-sillimanite granulites from Vizianagaram (samples EGB-09-45 from $18^{\circ} 09^{\prime} 17.7^{\prime \prime} \mathrm{N}, 83^{\circ} 25^{\prime}$ 07.3" E; EGB-09-47 from $18^{\circ} 09^{\prime} 17.3^{\prime \prime} \mathrm{N}, 83^{\circ} 25^{\prime} 24.6^{\prime \prime} \mathrm{E}$; and EGB-09-55 from $18^{\circ} 08^{\prime} 46.7^{\prime}$ ' N, 83 $26^{\circ}$ ' 27.4" E; Figure 1). Published $P-T$ constraints for this locality are peak conditions of $8-10 \mathrm{kbar}$ at $>1000{ }^{\circ} \mathrm{C}$, followed by near isobaric cooling to $750-800{ }^{\circ} \mathrm{C}$ and then near isothermal decompression to 4-5 kbar (Kamineni \& Rao, 1988; S. Sarkar, Dasgupta, \& Fukuoka, 2003). These $P-T$ estimates were infererred from univariant equilibria in petrogenetic grids in the simplified FMAS and KFMASH chemical systems, which neglect the complexity of natural rocks.

\section{3 | METHODS}

\section{1 | Phase equilibrium modelling}

Pressure-temperature pseudosections were calculated using THERMOCALC 3.40 and the ds6 internally consistent thermodynamic dataset (Holland \& Powell (2011); tc-ds62.txt, updated 6 February 2012). Pseudosections were calculated in the $\mathrm{Na}_{2} \mathrm{O}-\mathrm{CaO}-\mathrm{K}_{2} \mathrm{O}-\mathrm{FeO}-\mathrm{MgO}-$ $\mathrm{Al}_{2} \mathrm{O}_{3}-\mathrm{SiO}_{2}-\mathrm{H}_{2} \mathrm{O}-\mathrm{TiO}_{2}-\mathrm{Fe}_{2} \mathrm{O}_{3}$ (NCKFMASHTO) chemical system using the following solution models: biotite, garnet, cordierite, orthopyroxene, silicate melt, ilmenite from White et al. (2014); sapphirine from Wheller and Powell (2014), ternary feldspar from Holland and Powell (2003) and spinel-magnetite from White, Powell, and Clarke (2002). Whole rock compositions for initial $P-T$ pseudosections are based on whole rock XRF analyses for which loss-on-ignition (LOI) and $\mathrm{Fe}$ titration were used to constrain maximum $\mathrm{H}_{2} \mathrm{O}$ and $\mathrm{Fe}_{2} \mathrm{O}_{3}$ concentrations, respectively. However, since these initial $P-T$ pseudosections do not reproduce the inferred peak assemblages, domainal compositions were calculated based on the abundance and composition of minerals in selected areas in polished thin sections. The areas are inferred to have different mineral assemblages stable at the metamorphic peak. The proportion of minerals (Table 1) in each domain was measured using the TESCAN TIMA FEG-SEM at Curtin University (analytical procedures are given in Appendix S1), whereas representative mineral compositions were determined by EPMA using a Cameca SX51 at the University of Adelaide, for which the analytical protocol is can be found in Kelsey et al. (2017). The mineral compositions are provided in Table S1. In principle, this method returns

This article is protected by copyright. All rights reserved. 
comparable results to using mass-balance calculations on mineral proportions calculated from $\mathrm{X}$-ray maps or BSE images, but is automated so larger datasets can be collected. Volatile concentrations in cordierite were measured in cordierite grain-separates by SIMS using a Cameca IMS-4f ion microprobe at the University of Edinburgh (Harley, 1994); see Table S2. Measured $\mathrm{H}_{2} \mathrm{O}$ concentrations in cordierite and ideal $\mathrm{H}_{2} \mathrm{O}$ concentrations in biotite were used, together with the measured abundance of these minerals, to estimate $\mathrm{H}_{2} \mathrm{O}$ concentrations within domains. Mineral abbreviations follow Whitney and Evans (2010). The $P-T$ uncertainties for zero-mode isopleths bounding inferred prograde, peak and retrograde mineral assemblage fields were calculated using the calcsdnle script in THERMOCALC 3.40.

\section{2 $\mid$ Zircon geochronology and thermometry}

SHRIMP analysis of zircon was undertaken using the method detailed in Korhonen et al. (2013b). Zircon grains from samples EGB-09-45, -47 and -55 were separated from crushed rock using standard magnetic and heavy liquid methods. Grains were hand-picked and mounted on epoxy resin discs, polished to approximate half grain thickness then carbon coated. Zircon grains were imaged by cathodoluminescence (CL) with a Phillips XL30 scanning electron microscope located in the John de Laeter Centre, Curtin University using an acceleration voltage of $12 \mathrm{kV}$ and a working distance of $15 \mathrm{~mm}$. Cathodoluminescence imaging highlights distortions in the crystal lattice related to trace element distribution and radiation damage (Nasdala et al., 2003; Rubatto \& Gebauer, 2000). After imaging, the grain mounts were then cleaned ultrasonically with ethanol, petroleum ether and detergent (Decon), before being rinsed in distilled and deionized water, and dried in an oven at $60^{\circ} \mathrm{C}$. The mount was coated with a thin membrane of gold producing a resistivity of $10-20 \Omega \mathrm{m}$ across the disk.

Zircon U-Th-Pb isotope ratios were measured using the SHRIMP II in the John de Laeter Centre, Curtin University. Analysis spots on zircon are shown in Figure S1. The sensitivity for $\mathrm{Pb}$ isotope measurements in zircon was $21 \mathrm{cps} / \mathrm{pp} / \mathrm{nA}$, the primary beam current was 2.5-3.0 nA and mass resolution was $~ 5000$. Measured isotope ratios were corrected for common $\mathrm{Pb}$ based on the measured ${ }^{204} \mathrm{~Pb}$, in most cases resulting in a $<1 \%$ correction to the ${ }^{206} \mathrm{~Pb}$ counts. The Stacey and Kramers (1975) correction for common lead was used to correct $\mathrm{U}-\mathrm{Pb}$ ages. $\mathrm{Pb} / \mathrm{U}$ isotope ratios were corrected for instrumental interelement discrimination using the observed co-variation between $\mathrm{Pb}^{+} / \mathrm{U}^{+}$and $\mathrm{UO}^{+} / \mathrm{U}^{+}$ (Compston, Williams, \& Meyer, 1984; Hinthorne, Andersen, Conrad, \& Lovering, 1979) determined from interspersed analyses of zircon standard BR266. Standard BR266 is a single zircon megacryst from Sri Lanka with an age of $559 \pm 0.3 \mathrm{Ma},{ }^{206} \mathrm{~Pb} /{ }^{238} \mathrm{U}=0.09059$, $\mathrm{U}$ and Th concentrations of 909 and 201 ppm respectively (Stern, 2001). Raw data are presented in Table S3.

For laser ablation inductively coupled mass spectrometry (LA-ICP-MS) analyses, 11 zircon grains from three garnet-cordierite gneisses from Vizianagaram (samples EGB-0945, 47 and 55) were texturally characterized in thin section using CL imaging on a Tescan Mira3 XMU VP-FESEM at Curtin University. Concentrations of selected REEs and Ti, along with isotope ratios of $\mathrm{U}$, Th and $\mathrm{Pb}$, to monitor the age of the analysed zircon zone, were determined using the LA-ICP-MS facility at the John de Laeter Centre, Curtin University. The analysis time included 15-20 s of background and most analyses used spot sizes of $25 \mu \mathrm{m}$ (33 $\mu \mathrm{m}$ for larger grains). Grains were ablated using a $193 \mathrm{~nm}$ wavelength Resonetics RESOlution M-50A-LR, incorporating a ComplexPro 102 coherent excimerlaser with a $1.7 \mathrm{~J} / \mathrm{cm}^{2}$ energy density at the sample surface and a $7 \mathrm{~Hz}$ repetition rate. Isotope ratios were measured with an Agilent 7700x ICP-MS system with high purity Ar plasma gas with a

This article is protected by copyright. All rights reserved. 
$0.98 \mathrm{l} / \mathrm{min}$ flow rate. Isotopes were monitored for $0.01 \mathrm{~s}$, except ${ }^{204} \mathrm{~Pb},{ }^{206} \mathrm{~Pb},{ }^{207} \mathrm{~Pb}(0.03 \mathrm{~s})$,

${ }^{232} \mathrm{Th}$ and ${ }^{238} \mathrm{U}(0.0125 \mathrm{~s})$. Data reduction was undertaken using the Iolite v.3 software (Paton, Hellstrom, Paul, Woodhead, \& Hergt, 2011). Reduction of U-Th-Pb isotopic compositions used natural zircon standard $91500(1062 \pm 0.4 \mathrm{Ma}$; Wiedenbeck et al. (1995)) as an external reference material and ${ }^{238} \mathrm{U} /{ }^{235} \mathrm{U}=137.82$ as an internal standard. For zircon trace element analysis, glass standard NIST 612 was used as an external reference material and stoichiometric $49.00 \mathrm{wt} \%{ }^{91} \mathrm{Zr}$ as an internal standard (Liu et al., 2010); analyses returning anomalous (non-stoichometric) Si concentrations were discarded. The calibration of Ferry and Watson (2007) at $10 \mathrm{kbar}$ was used for Ti-in-zircon thermometry, as there is no published calibration of the pressure dependence for this thermometer (Ferry \& Watson, 2007;

Tomkins, Powell, \& Ellis, 2007). Analytical data are provided - U-Pb data in Table S4 and REE/Ti concentrations in Table S5.

\subsection{Monazite geochronology}

Thin section fragments from samples EGB-09-45, -47 and -55 containing monazite grains were mounted along with chips of monazite standard ind $-1\left[509 \mathrm{Ma},{ }^{2-6} \mathrm{~Pb} /{ }^{238} \mathrm{U}=0.082133\right.$; Korhonen et al. (2011)] and prepared using a similar procedure to the zircon mounts. Monazite was imaged using a backscatter electron (BSE) detector on a Philips XL30 SEM located at the John de Laeter Centre, Curtin University using a working distance of $5 \mathrm{~mm}$ and an accelerating voltage of $20 \mathrm{kV}$. U-Pb isotope measurements on the SHRIMP II used a $\sim 0.5 \mathrm{nA} \mathrm{O}_{2}{ }^{-}$primary beam, $10 \mu \mathrm{m}$ spots, a 5-scan duty cycle and a mass resolution of $\sim 5000$. Additional details regarding the Curtin SHRIMP procedures for measurement of monazite are outlined by Foster, Kinny, Vance, Prince, and Harris (2000). BSE images of monazite grains are given in Figure S2, and U-Pb data tables for monazite analyses are given in Table S4.

\section{4 | RESULTS}

\section{1 | Petrography}

The petrological features of samples EGB-09-45 and -47 are illustrated in Figure $2 a, b$ (EGB-09-45), and Figures 2c-f and 3 (EGB-09-47).

\subsection{1 | Sample EGB-09-45}

Sample EGB-09-45 is a granulite with discrete compositional layers $\sim 5 \mathrm{~mm}$ thick. Individual layers are dominated either by garnet-sillimanite-spinel-cordierite (domain 1; Figure 2a) or orthopyroxene-sillimanite-cordierite-spinel (domain 2; Figure 2b), in which a weak foliation is defined by prismatic sillimanite. K-feldspar, plagioclase and quartz are present in all domains. Accessory minerals include ilmenite, composite grains of spinel-magnetite, zircon and monazite. Garnet contains abundant inclusions of quartz, K-feldspar and, rarely, spinelmagnetite mantled by sillimanite. Cordierite in domain 1 occurs as $\sim 5 \mathrm{~mm}$ poikiloblasts containing quartz and K-feldspar inclusions, and as thin seams separating sillimanite from garnet (Figure 2a). Prismatic sillimanite commonly surrounds spinel and ilmenite.

Orthopyroxene and sillimanite occur throughout domain 2, but are always separated by a thin layer of cordierite (Figure 2b). Cordierite also occurs as patchy intergrowths with K-feldspar and quartz.

We interpret the peak assemblages in domains 1 and 2 to be garnet-sillimanite-spinel (Figure 2a; domain 1 in Figure $4 \mathrm{a}$ ) and orthopyroxene-sillimanite-spinel (Figure 2b; domain 2 in Figure 4a), respectively, each with K-feldspar, quartz and ilmenite. Fine-grained interstitial cordierite-quartz intergrowths are considered to be a retrograde feature. 


\subsection{2 | Sample EGB-09-47}

Sample EGB-09-47 is a garnet-sillimanite-orthopyroxene-cordierite-sapphirine-spinelbearing metapelitic granulite. Large grains $(\sim 3 \mathrm{~cm})$ of garnet, interpreted to record an early prograde growth stage (garnet ${ }_{1}$ ), have inclusions of cordierite, isolated sapphirine, quartz, spinel, magnetite, ilmenite, rutile and zircon (Figure 2c-e). Rarely, euhedral sillimanite is observed in direct contact with garnet ${ }_{1}$ (Figure 2f). A second generation of garnet (garnet ${ }_{2}$ ) occurs as euhedral grains $\sim 200 \mu \mathrm{m}$ across containing abundant lobate inclusions of quartz. Garnet $_{2}$ commonly coexists with granoblastic K-feldspar and quartz, consistent with it forming in the presence of partial melt (Waters (2001); Figures 2c,f and 3b,g). Orthopyroxene grains up to $\sim 500 \mu \mathrm{m}$ across occur in layers dominated by cordierite and sillimanite (Figure 3 b,d). Commonly, domains containing garnet ${ }_{2}$ and $\mathrm{K}$-feldspar contain coarse biotite (Figure 2c). Sillimanite, orthopyroxene and spinel, which are separated by thin seams of cordierite, occur in clearly defined layers, similar to those in EGB-09-45 (Figure 3b d). Sapphirine porphyroblasts occur within the K-feldspar-quartz dominated matrix and are mantled by cordierite or sillimanite, separating it from quartz (Figure 3d,f). Quartz is present throughout the matrix and as inclusions in garnet ${ }_{1}$, so is inferred to have been present throughout the metamorphic evolution of EGB-09-47.

Garnet $_{1}$ grains are commonly replaced at their margins by symplectites comprising fine intergrowths of orthopyroxene and cordierite with or without sillimanite (Figures $2 \mathrm{f}$ and 3a). In some cases, the symplectites occur in close proximity to biotite (Figure $2 \mathrm{f}$ ). A fabric defined by compositional layering wraps the garnet ${ }_{1}$ porphyroblasts. The layering comprises three garnet-bearing associations: (i) a granoblastic areas comprising euhedral garnet ${ }_{2}$ and Kfeldspar, (ii) areas with garnet ${ }_{2}$ and cordierite, and (iii) fine intergrowths of garnetsillimanite-cordierite-K-feldspar-quartz (Figures $2 \mathrm{c}$ and $3 \mathrm{~b}$ ). In addition, there are aluminous layers dominated by orthopyroxene and sillimanite (Figure 3b), which lack garnet and are separated from garnet-bearing domains by K-feldspar-cordierite-quartz horizons. Furthermore, several corona textures occur throughout the sample. These are (from core to rim): spinel|sapphirine|sillimanite|garnet 2 |qz (Figure 3c) and ilmenite|sillimanite|garnet 2 |quartz (Figure 3e) coronae, both of which are developed at the margins of garnet ${ }_{1}$, and spinel|sillimanite|K-feldspar and orthopyroxene|cordierite|sillimanite coronae that occur in garnet-absent orthopyroxene-sillimanite layers (Figure 3d). Garnet 2 never exhibits symplectic intergrowths at its margins, regardless of textural association.

The textural development of EGB-09-47 is complex. However, we interpret that the prograde growth of garnet ${ }_{1}$ occurred in equilibrium with cordierite, sapphirine and quartz. Inferred domainal peak assemblages include: garnet-sapphirine-sillimanite (Figure 2c; Figure $4 b$, domain 4), garnet-orthopyroxene-sillimanite (Figures $2 \mathrm{f}$ and $3 \mathrm{a}$; Figure $4 \mathrm{~b}$, domain 3) and orthopyroxene-sapphirine-sillimanite-spinel-(porphyroblastic) cordierite (Figure 3d,h; Figure 4b, domains 1 and 2), each with K-feldspar and quartz. The retrograde breakdown of peak phases has led to the development of fine-grained cordierite-sillmanitequartz intergrowths (Figures 2e,f,h and $4 \mathrm{~b}$ ) within the orthopyroxene-sillimanite-spinel bearing layers. However, coarse inclusion-poor cordierite distinct to that between orthopyroxene and sillimanite is interpreted to be part of the domainal peak assemblage (i.e. Figure 3h; Figure 4b, domains 1 and 2). Domains containing euhedral garnet 2 and rich in Kfeldspar (Figure 3g) are interpreted as relict leucosomes formed with cooling through garnet stability fields.

This article is protected by copyright. All rights reserved. 


\section{2 | Phase equilibrium modelling 4.2.1 | Whole rock compositions}

For samples EGB-09-45 and -47, orthopyroxene and sillimanite are interpreted to have stably coexisted at the metamorphic peak in some petrographic domains (Figures $2 \mathrm{~b}$ and $3 \mathrm{a}, \mathrm{d}, \mathrm{f})$, but orthopyroxene is not predicted to be stable with sillimanite anywhere in the $P-T$ pseudosection based on the whole rock composition for either sample (Figure S3).

Furthermore, as these interpreted peak assemblages vary on a centimetre scale in each sample (Figure 4), the rocks are inferred to have become domainal at UHT conditions.

The evidence for domainal differences in mineral assemblages in both samples likely reflects compositional variations in $X(\mathrm{Mg})$ [molar $\mathrm{MgO} /(\mathrm{MgO}+\mathrm{FeO})]$ and $\mathrm{A} / \mathrm{AFM}$ [molar $\left.\mathrm{Al}_{2} \mathrm{O}_{3} /\left(\mathrm{Al}_{2} \mathrm{O}_{3}+\mathrm{MgO}+\mathrm{FeO}\right)\right]($ Table 2; Thompson, 1957). To investigate these different domains, $P-T$ pseudosections were calculated using bulk compositions derived from selected areas within the thin sections (shown as domains in Figure 4). Simplified $P-T$ phase diagrams for these areas that highlight the stability fields for the main silicate minerals from 4-10 kbar and $750-1050^{\circ} \mathrm{C}$ are shown in Figures 5 (sample EGB-09-45) and 6 (sample EGB-09-47). The full phase diagrams on which these simplified diagrams are based are given in Figures S4 and S5, respectively.

\subsection{2 | Domainal compositions}

Sample EGB-09-45

A $P-T$ phase diagram calculated for the composition (Table 2 ) of a garnet-sillimanitespinel-cordierite-bearing domain (domain 1 in Figure 4a; Table 2), with $X(\mathrm{Mg})=0.32$ and $\mathrm{A} / \mathrm{AFM}=0.58$, is shown in Figure $5 \mathrm{a}$. The presence of $\sim 25$ vol. $\%$ cordierite and $<1$ vol.\% biotite corresponds to $0.04 \mathrm{~mol} \% \mathrm{H}_{2} \mathrm{O}$ in the bulk composition of this domain (Figure 4a). For this $\mathrm{H}_{2} \mathrm{O}$ content, at $>7.5 \mathrm{kbar}$ the calculated solidus occurs at $860-870^{\circ} \mathrm{C}$, stepping up to $\sim 1000^{\circ} \mathrm{C}$ at $<6.5 \mathrm{kbar}$. For the $X\left(\mathrm{Fe}^{3+}\right)$ of the domain 1, which is based on mineral stoichiometry, spinel is predicted to be stable at ultrahigh-temperatures at pressures up to 9 kbar. Magnetite with or without spinel is stable except at the highest temperatures and pressures below $\sim 9$ kbar. Including the calculated $2 \sigma$ errors on the end-member thermodynamic data, the interpreted peak assemblage of garnet-melt-sillimanite-K-feldsparmagnetite-ilmenite-quartz for domain 1 in sample EGB-09-45 occurs at $>7 \mathrm{kbar}$ and $>850^{\circ} \mathrm{C}$ (area outlined by the red dashed line in Figure 5a). This field is limited to lower $P-T$ by cordierite-in, biotite-in and orthopyroxene-in equilibria. The development of retrograde cordierite is consistent with decompression with or without cooling into fields at $\sim 7-8 \mathrm{kbar}$ and $\sim 800-950^{\circ} \mathrm{C}$, and final crystallization of melt at the elevated (residual) $\mathrm{H}_{2} \mathrm{O}$ undersaturated solidus (area outlined by the blue dashed line in Figure 5a).

A $P-T$ phase diagram for the composition of an orthopyroxene-sillimanite-spinelcordierite-bearing domain (domain 2 in Figure 4a; Table 2) is shown in Figure 5b. This composition has $X(\mathrm{Mg})=0.45$ and $\mathrm{A} / \mathrm{AFM}=0.44 ; \mathrm{H}_{2} \mathrm{O}$ content is estimated to be $\sim 0.01 \mathrm{~mol}$ $\%$ based on the mode of cordierite and biotite. The solidus is located at $\sim 885^{\circ} \mathrm{C}$ above $\sim 8$ kbar and steps up to $>1000^{\circ} \mathrm{C}$ at $<6.5 \mathrm{kbar}$. The solidus is at a higher temperature than the solidus for domain 1 due to a lower $\mathrm{H}_{2} \mathrm{O}$ content, which is a consequence of the lower mode of cordierite and absence of biotite. Compared to domain 1, spinel is stable to lower temperatures $\left(\sim 775^{\circ} \mathrm{C}\right)$ at $\sim 4.5 \mathrm{kbar}$, extending to $1100^{\circ} \mathrm{C}$ and higher at $>9 \mathrm{kbar}$. The inferred peak assemblage of orthopyroxene-melt-sillimanite-ilmenite-spinel-magnetite-Kfeldspar-quartz occurs in a field at $P-T$ conditions of $6.7-7.9 \mathrm{kbar}$ and $970-1020^{\circ} \mathrm{C}$ (area outlined by the red dashed line, Figure $5 \mathrm{c}$ ). This peak field is limited by spinel out to lower- $T$,

This article is protected by copyright. All rights reserved. 
garnet in to higher- $P$, magnetite out to higher- $T$ and cordierite in to lower- $P$. The development of retrograde cordierite is consistent with minor decompression with or without cooling, and crystallization of all melt at the $\mathrm{H}_{2} \mathrm{O}$-undersaturated solidus (area outlined by the blue dashed line, Figure 5b).

\section{Sample EGB-09-47}

Four $P-T$ phase diagrams were calculated using bulk compositions (Table 2) derived from the areas shown in Figure 4b (Table 2). Domains 1 and 2 are orthopyroxene-sapphirinesillimanite-spinel-cordierite-bearing areas that contain sparse and abundant quartz, respectively (Figure 4b). Domain 1 has $X(\mathrm{Mg})=0.61$ and $\mathrm{A} / \mathrm{AFM}=0.50$, whereas domain 2 has $X(\mathrm{Mg})=0.59$ and $\mathrm{A} / \mathrm{AFM}=0.49$. In both cases, $\mathrm{H}_{2} \mathrm{O}$ contents are estimated to be $<0.07$ mol.\% based on the mode of cordierite. Within the $P-T$ range of interest for both domains (Figure 6a,b), quartz is predicted in all fields and the solidus occurs at $\sim 900^{\circ} \mathrm{C}$ for $>8 \mathrm{kbar}$, stepping up to $\sim 1000^{\circ} \mathrm{C}$ or more at $<6.5 \mathrm{kbar}$. In both cases, garnet is present above $\sim 4 \mathrm{kbar}$ at low- $T$ and above, extending to $\sim 8 \mathrm{kbar}$ or above at the extreme temperature of $1100^{\circ} \mathrm{C}$. Cordierite is predicted to be stable below pressures of between $\sim 8$ and $6.5 \mathrm{kbar}$ at $\sim 900$ $1050^{\circ} \mathrm{C}$, respectively. Sapphirine is stable above $\sim 1000^{\circ} \mathrm{C}$ at intermediate pressures in both domains; the decreased stability of sapphirine compared to sample EGB-09-45 likely reflects the relatively low $X\left(\mathrm{Fe}^{3+}\right)$. The peak assemblage for both domains is inferred to be orthopyroxene-sapphirine-sillimanite-spinel-cordierite-K-feldspar-quartz-rutile-ilmenite (cordierite occurs as coarse porphyroblasts; domains 1 and 2, Figures $3 \mathrm{~h}$ and $4 \mathrm{~b}$ ). The assemblage occurs in overlapping $P-T$ fields (taking into account the $2 \sigma$ uncertainties) at $\sim 6.4-7.2 \mathrm{kbar}$ and $975-1025^{\circ} \mathrm{C}$ (area outlined by the red dashed line, Figure $6 \mathrm{a}, \mathrm{b}$ ). The boundaries of the peak field are garnet-in at high- $P$, sillimanite-out at low- $T$, rutile-out at low- $P$ and low- $T$, and for domain 2 , sapphirine-out at low- $P$.

A $P-T$ phase diagram for domain 3 , which contains garnet-orthopyroxenesillimanite-cordierite (Figure 4b, Table 2), is shown in Figure 6c. Domain 3 has $X(\mathrm{Mg})=$ 0.54 and $\mathrm{A} / \mathrm{AFM}=0.48 ; \mathrm{H}_{2} \mathrm{O}$ content is estimated to be $\sim 0.04$ mol.\% based on the mode of cordierite. Quartz is present in all assemblage fields, while orthopyroxene is only predicted at intermediate pressures of $\sim 5-7 \mathrm{kbar}$ and at $750^{\circ} \mathrm{C}$ and $\sim 6-7 \mathrm{kbar}$ at $950^{\circ} \mathrm{C}$, and up to a maximum temperature of $990^{\circ} \mathrm{C}$. Sapphirine is stable above $950^{\circ} \mathrm{C}$ at intermediate pressures. The peak assemblage of garnet-melt-orthopyroxene-sillimanite-K-feldspar-quartzilmenite-rutile is stable in a small $P-T$ field at $\sim 7.2 \mathrm{kbar}$ and $\sim 975^{\circ} \mathrm{C}$ (the area outlined by the red dashed line, Figure $6 \mathrm{c}$ ). This field is constrained by orthopyroxene-out to higher- $P$, sapphirine-in to higher- $T$ and cordierite-in to lower- $P$ and lower- $T$. The retrograde assemblage with additional cordierite and plagioclase occurs between $\sim 6-7 \mathrm{kbar}$ at 750 $960^{\circ} \mathrm{C}$. The retrograde field, which is subsolidus and based on the appearance of cordierite, is restricted by plagioclase-out and orthopyroxene-in at high- $P$, biotite-in at low- $T$, rutile-out at low- $P$ and sapphirine-in at high- $T$ (area outlined by the blue dashed line, Figure $6 \mathrm{c}$ ).

Within domain 4 (Figure 4b), symplectites of cordierite-orthopyroxene-sillimanite$\mathrm{K}$-feldspar (e.g. Figures $2 \mathrm{f}$ and $3 \mathrm{a}$ ) partially replace garnet in the garnet $_{1}-$ melt-sapphirine- $^{-}$ sillimanite-K-feldspar-plagioclase-spinel-ilmenite-rutile-quartz assemblage. This is interpreted to record the breakdown of peak garnet in the presence of melt. For this domain, $X(\mathrm{Mg})=0.49$ and $\mathrm{A} / \mathrm{AFM}=0.44 ; \mathrm{H}_{2} \mathrm{O}$ content is estimated to be $\sim 0.04 \mathrm{~mol} . \%$ based on the mode of cordierite. In the phase diagram for domain 4 (Figure $6 \mathrm{~d}$ ) within the $P-T$ range considered, the solidus occurs at $\sim 875^{\circ} \mathrm{C}$ at pressures greater than $\sim 7.4$ kbar stepping up to $1000-1050^{\circ} \mathrm{C}$ at pressures below 6-6.5 kbar. Orthopyroxene-bearing equilibria occur in the high- $T$ and low- $P$ quadrant, above $\sim 930^{\circ} \mathrm{C}$ from $\sim 4$ to $\sim 8 \mathrm{kbar}$, and in a small window below $\sim 870^{\circ} \mathrm{C}$ between $\sim 5$ and $\sim 6.3 \mathrm{kbar}$. The inferred peak assemblage field of garnet $_{1}-$ melt $^{-}$ sapphirine-sillimanite-K-feldspar-plagioclase-spinel-ilmenite-rutile-quartz field is

This article is protected by copyright. All rights reserved. 
consistent with pressures of $\sim 6-8 \mathrm{kbar}$ and temperatures in excess of $1000^{\circ} \mathrm{C}$ (area outlined by the red dashed line in Figure $6 \mathrm{~d}$ ). The cordierite-bearing garnet $_{1}$-cordierite-sapphirinesillimanite-K-feldspar-plagioclase-spinel-ilmenite-rutile-quartz field indicates that the interpreted retrograde evolution for this domain is consistent with minor decompression across the solidus (area outlined by the blue dashed line in Figure 6d).

\section{4 | Zircon geochronology and thermometry}

\subsubsection{Zircon morphology and petrography}

The characteristic morphology of zircon grains in CL is shown in Figure 7. Grains that show clear oscillatory zoning patterns characteristic of magmatic zircon are rare; most grains have textures consistent with crystallization of zircon from anatectic melt generated during UHT metamorphism and/or recrystallization during fluid mediated processes (R. J. M. Taylor, Kirkland, \& Clark, 2016). Core domains in zircon from samples EGB-09-45, -47 and -55 are variable, with sector-zoned, 'fir-tree' and 'soccer ball' textures all present (Figure 7a-d). Other examples have inclusion-rich cores with low CL responses characterised by convolute zoning; where overgrowths are present, they have cuspate boundaries with the cores (Figure 7e,f). Cores with low CL response are interpreted as inherited grains.

Overgrowths are common; the outermost layers generally have a lower CL response and are texturally homogenous, rarely showing parallel sector zoning that is discontinuous with high CL response 'fir-tree' and 'soccer ball' sector-zoned regions closer to grain cores (EGB-09-55; Figure 7a). In sample EGB-09-45, analysed grains occur adjacent to ilmenite and sillimanite, and occur in both orthopyroxene-sillimanite-cordierite- and garnetsillimanite-cordierite-spinel-bearing domains. However, zircon grains in direct contact with garnet are not observed in this study. Zircon grains in sample EGB-09-47 occur in several domains. Large, sector-zoned grains (e.g. Figure 7c) are found in orthopyroxene-sillimanitebearing domains and within the interstitial K-feldspar-cordierite-quartz matrix. A variety of 'soccer ball' and oscillatory-zoned zircons are found in garnet ${ }_{1}$ and garnet ${ }_{2}$-bearing domains

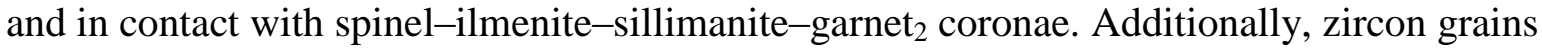
in garnet 2 -bearing domains within sample EGB-09-47 commonly show sector zoning, accompanied with fine-scale zoning patterns (Figure 7d).

\subsection{2 $\mid \mathrm{U}-\mathrm{Pb}$ geochronology}

High precision SHRIMP analyses $(n=60)$ from samples EGB- $-09-45,-47$ and -55 provide timing constraints (Table S3; Figure 8a, b; red ellipses) on the metamorphic events recorded in these rocks. Dark-CL inherited cores (Figure S1) return three concordant ages $c$. 2500$2400 \mathrm{Ma}$, and a single concordant age of $c .2000 \mathrm{Ma}$. The ${ }^{238} \mathrm{U} /{ }^{206} \mathrm{~Pb}$ ages define a probability density function (PDF) with a primary peak at $c$. $950 \mathrm{Ma}$ and secondary peak at $c$. 550-500 Ma (Figure 8a). Analyses from sector-zoned grains yield concordant ages of $c$. 1050-800 Ma, with an age span of $c .200 \mathrm{Ma}$ often apparent within single sector zoned grains (Figure 7c). A further group of analyses return ages between $c .800$ and $600 \mathrm{Ma}$ that are discordant and define a broadly Pan-African lower intercept. Three analyses from zircon overgrowths return a weighted mean Concordia age of $511 \pm 6 \mathrm{Ma}(\mathrm{MSWD}=0.068$, Prob. $=0.79)$.

\subsection{3 | Trace element patterns}

Chondrite-normalised rare earth element (REE) patterns of zircon within the garnet-bearing sample EGB-09-47 are plotted in Figure 8d. Notably, sector-zoned zircon grains in garnetabsent, orthopyroxene-sillimanite-bearing domains in this sample have depleted heavy REE (HREE) patterns (Figure 8d, solid lines) relative to grains in garnet-bearing domains. Zircon grains in garnet ${ }_{1}$ or garnet ${ }_{2}$-bearing domains show a wider spread of REE patterns, may have a more pronounced Eu anomaly, and exhibit a wider range of HREE concentrations - often 
enriched by up to an order of magnitude. In this sample, there is no clear correlation between normalized REE patterns and internal zircon morphology. The only apparent REE trend with age is HREE enrichment associated with spot analyses from some zircon rims in EGB-09-45 and -55 (Tables S4 and S5). However, a range of higher $\mathrm{Yb} / \mathrm{Gd}$ ratios is apparent for zircon spots across all age populations from grains coexisting with garnet (Figure 8d).

\subsection{4 | Ti-in-zircon thermometry}

For zircon with concordant ages determined by LA-ICP-MS (Figures 8c and 9a), Ti-inzircon thermometry was used to assess crystallization temperatures for the same spots. The Ti-in-zircon temperatures yield a bimodal PDF (Figure 9a) corresponding to the age peaks, with Ti-in-zircon temperatures of $\sim 905^{\circ} \mathrm{C}$ and $\sim 810^{\circ} \mathrm{C}$. The data forms three clusters (Figure $9 \mathrm{~b}$ ): the first at around $940-880^{\circ} \mathrm{C}$ in the age range $c .1000-880 \mathrm{Ma}$, which are interpreted to represent the peak of UHT metamorphism and which correspond to sector zoned domains in zircon; the second at $\sim 900^{\circ} \mathrm{C}$ between $c .800$ and $600 \mathrm{Ma}$, although the ages in this interval determined by SHRIMP are discordant, suggesting that the temperatures do not record a discrete metamorphic event; and; the third at $\sim 820-800^{\circ} \mathrm{C}$ and $c$. 550-500 Ma corresponding to low-response CL zircon rims. The assumption used here that $a_{\mathrm{TiO} 2}=1$ leads to an underestimate of temperature for rutile-absent domains by up to $\sim 70{ }^{\circ} \mathrm{C}$ (Ferry \& Watson, 2007). The peak pressure of $\sim 7 \mathrm{kbar}$ here, compared to the 10kbar calibration of this thermometer may result in a further underestimation of $\sim 15^{\circ} \mathrm{C}$, hence the Ti-in-zircon temperatures should be regarded as minima. An orthogonal regression technique (Krystek \& Anton, 2007) was used to obtain an average cooling rate of $0.13 \pm 0.08^{\circ} \mathrm{C} / \mathrm{Ma}$ from concordant LA-ICP-MS ${ }^{238} \mathrm{U} /{ }^{206} \mathrm{~Pb}$ ages and Ti-in-zircon temperatures associated with the c.1000-880 Ma UHT event (Figure 9a). This result is consistent with very slow cooling towards the elevated solidus.

\section{5 | Monazite geochronology}

\subsubsection{Monazite morphology and petrography}

Monazite grains in samples EGB-09-47 and -55 vary between 20 and $200 \mu \mathrm{m}$ in diameter and have a variety of textures. Core domains may exhibit planar features with varying BSE response, similar to sector zoned zircon grains (Figure 9a,b). Several show mottled, patchy zoning (Figure 9b) or lobate inclusions that cut across features in inner domains. Almost all grains have overgrowths $\sim 20 \mu \mathrm{m}$ thick, with a darker BSE response, that cross-cut internal zoning (Figure 10b)

\subsection{2 $\mid$ Monazite U-Pb geochronology}

Monazite $\mathrm{U}$, Th and $\mathrm{Pb}$ isotope ratios for samples EGB-09-47 and -55 are given in Table S3 and displayed in Tera-Wasserberg concordia plots in Figure 11. Monazite in sample EGB09-47 (Figure 11a) yields concordant ages of $c$. 950-850 Ma. A single analysis with an age of $550 \pm 43 \mathrm{Ma}$ is within $2 \sigma$ error of the concordia. Monazite grains in sample EGB-09-55 yield ages that spread along Concordia from $c .950$ to $c .800 \mathrm{Ma}$. Three data plot on Concordia within error and yield ages between c. $595 \mathrm{Ma}$ and $c .485 \mathrm{Ma}$.

\section{5. | DISCUSSION}

\subsection{Evidence for domainal equilibration volumes during UHT metamorphism}

Samples EGB-09-45 and -47 are high-grade metamorphic rocks with mineral assemblages that are variable over length scales as small as $\sim 5 \mathrm{~mm}$. Compositional layers preserved on a centimetre scale (Figure 3b) suggest the possibility of preservation of primary compositional layering in the sedimentary protoliths. Peak mineral associations (all of which include matrix

This article is protected by copyright. All rights reserved. 
K-feldspar and quartz) in the different layers include garnet-sillimanite-ilmenite (Figure 2a), orthopyroxene-sillimanite-spinel \pm cordierite (Figure $2 b$ ), garnet-sapphirine-sillimanite (Figure 2c), garnet-orthopyroxene-sillimanite (Figure 2g) and orthopyroxene-sillimanitesapphirine-spinel \pm cordierite (Figure $3 \mathrm{~d}, \mathrm{~h}$ ). In sample EGB-09-45, garnet-sillimaniteilmenite-bearing domains have an $X(\mathrm{Mg})$ that is significantly lower (by 0.13 ) than the orthopyroxene-sillimanite-spinel-bearing domains, but an A/AFM that is higher by 0.14 . Similarly, in sample EGB-09-47, the garnet-sapphirine-sillimanite-bearing domain 4 has an $X(\mathrm{Mg})$ that is lower by 0.12 than the orthopyroxene-sillimanite-sapphirine-spinel-bearing domain 1 but, in this case, is less aluminous with an A/AFM by 0.06. These observations demonstrate that the rocks preserved significant differences in two compositional parameters critical to metapelitic phase equilibria $-X(\mathrm{Mg})$ and $\mathrm{A} / \mathrm{AFM}-\mathrm{on}$ a centimetre scale. Similarly small domains occur in various granulite facies xenoliths that record temperatures of $\sim 1000^{\circ} \mathrm{C}$, for example in the northern limb of the Bushveld Complex (Johnson, Brown, \& White, 2010) and the Cortlandt Complex (Dorfler, Caddick, \& Tracy, 2015).

Felsic domains dominated by coarse-grained K-feldspar and quartz are interpreted as leucosome; these are interspersed between garnet-sillimanite-spinel- and orthopyroxenesillimanite-spinel-bearing layers in EGB-09-45, and commonly surround garnet ${ }_{1}$ porphyroblasts in EGB-09-47 (Figures $2 \mathrm{~h}$ and $3 \mathrm{~g}$ ). In both samples, cordierite, which is interpreted to have grown variably as part of the peak assemblage (Figures $3 \mathrm{~h}$ and $6 \mathrm{a}, \mathrm{b}$ ) or during the high- $T$ retrograde evolution (Figures 5 and $6 \mathrm{c}, \mathrm{d}$ ), is the only primary hydrous mineral. Consequently, the $\mathrm{H}_{2} \mathrm{O}$ content of the domains may be determined based on the measured abundance and volatile content of cordierite, providing cordierite was part of the close-to-peak assemblage.

In sample EGB-09-47, small millimetre scale leucosome domains consist of inclusion-rich euhedral garnet grains ( garnet $_{2}$ ) in a granoblastic K-feldspar-quartz matrix (Figure $3 \mathrm{~g}$ ) with rare large biotite laths (Figure 2c,g). These domains are commonly juxtaposed against cordierite-quartz intergrowths. The orthopyroxene-cordierite-sillimanite symplectites that surround garnet ${ }_{1}$ are not found associated with garnet ${ }_{2}$, which suggests the formation of such symplectites records melt crystallization. Late biotite and the preservation of pristine cordierite potentially may be due to an increase in $a\left(\mathrm{H}_{2} \mathrm{O}\right)$ due to the preferential crystallization of $\mathrm{CO}_{2}$-bearing cordierite, as $D_{\mathrm{CO} 2 \text { (liq)/CO2(cordierite) }}<D_{\mathrm{H} 2 \mathrm{O}(\mathrm{liq}) / \mathrm{H} 2 \mathrm{O} \text { (cordierite) }}$ (Thompson, Harley, \& Carrington, 2001). However, $a-X$ models incorporating $\mathrm{CO}_{2}$ into melt and cordierite are required to construct appropriate pseudosections to test this proposal.

\section{$5.2 \mid P-T$ evolution}

In some cases, constraints on the prograde path followed by rocks may be made by using inclusions within prograde to peak minerals. For example, sample EGB-09-47 contains garnet prophyroblasts with inclusions of cordierite, sillimanite, sapphirine and spinel (Figure $2 \mathrm{c}-\mathrm{e})$. However, along the prograde evolution at temperatures above the wet solidus ( 650 ${ }^{\circ} \mathrm{C}$ ), the composition of these granulites would have been constantly evolving due to the production and loss of melt regardless of the scale of equilibration. Consequently, the bulk composition of the prograde equilibration domain is unknown, and phase equilibrium modelling based on these inclusion suites is not appropriate for quantitatively evaluating $P-T$ conditions.

A $P-T$ path for the peak and retrograde evolution of the granulites of this study is proposed based on mineral assemblages and microstructures inferred to have developed during the peak and retrograde evolution using phase diagrams constructed for selected domains within samples EGB-09-45 and -47. $P-T$ pseudosections for the composition of selected areas in thin sections reproduce the interpreted domainal peak assemblages. Peak metamorphic mineral associations include coexisting orthopyroxene and sillimanite in

This article is protected by copyright. All rights reserved. 
domain 2 in sample EGB-09-45 (Figure 5c) and domain 1 in sample EGB-09-47 (Figure 6b). Cordierite is inferred to have been stable at peak conditions in domains 1 and 2 of sample EGB-09-47, where it occurs as coarse porphyroblasts (Figures $3 \mathrm{~g}$ and $6 \mathrm{~b}, \mathrm{c}$ ), in addition to its occurrence as poikiloblastic grains with quartz and sillimanite inclusions and as seams separating orthopyroxene and sillimanite (Figure 3d). Coexisting garnet and sillimanite without cordierite are inferred in the peak assemblage for domain 1 in sample EGB-09-45 (Figure 5b), garnet-sillimanite-orthopyroxene for domain 3 of sample EGB-09-47 (Figure 6d) and garnet-sillimanite-sapphirine for domain 4 in sample EGB-09-47 (Figure 6e). Peak fields for these various domains record similar conditions. Peak stability fields overlap implying temperatures of $965-1050^{\circ} \mathrm{C}$, and pressures must extend to $\sim 6.8-8.3 \mathrm{kbar}$ where peak stability fields of EGB-09-45 domains 1 and 2 overlap, as summarised in Figure 12a.

For most domains, the stability fields for post-peak assemblages that record the breakdown of peak minerals are constrained by cordierite-bearing equilibria. These retrograde fields generally overlap the peak assemblage stability fields, but consistently extend down temperature, always at a lower pressure (Figure 12a). For every pair of modelled peak and retrograde assemblage, the inferred retrograde assemblages are consistent with minor decompression (on the order of $<1 \mathrm{kbar}$ ). In all modelled compositions, the elevated solidus is characterised by a sharp increase in temperature $\left(100-200^{\circ} \mathrm{C}\right)$ from higher to lower pressure, which occurs between 8.0 and $6.5 \mathrm{kbar}$ (Figure 12b). Post peak $P-T$ vectors for each domain indicate minor decompression and cooling from their respective peak field. Consequently, the majority of $P-T$ vectors coincide with $<1 \mathrm{kbar}$ of decompression from the inferred metamorphic peak conditions $\left(\sim 6.8-8.3 \mathrm{kbar}\right.$ at $\left.965-1050^{\circ} \mathrm{C}\right)$, leading to the $\mathrm{H}_{2} \mathrm{O}$-undersaturated solidus (Figure 12b), with final crystallization of melt and growth of cordierite. Symplectic replacement of garnet by orthopyroxene, sillimanite and cordierite, fine grained cordierite-sillimanite-quartz intergrowths (Figure 2f), and cordierite seams between orthopyroxene and sillimanite can all be achieved in the presence of melt by crossing the garnet+cordierite $+\mathrm{K}-$ feldspar+quartz $=$ orthopyroxene+sillimanite + melt univariant KFMASH reaction from high to low $P-T$ (Harley, 2008). Similar textures around this univariant have been ascribed to chemical potential gradients of $\mathrm{MgO}$ and $\mathrm{FeO}$, decompression of $<<1 \mathrm{kbar}$ and the local presence of melt (Doukkari, Dienar, Ouzegane, \& Kienast; 2018). However, pressure variations on the order of $1 \mathrm{kbar}$ are probably within the uncertainties associated with phase equilibrium modelling (Powell \& Holland, 2008), Increasing $\mathrm{CO}_{2}$ concentration in the system would enlarge the cordierite stability field to higher pressure, as $\mathrm{CO}_{2}$ partitions preferentially into cordierite rather than melt under granulite facies conditions (Harley, 2008; Thompson, Harley \& Carrington, 2001). As such, systems which include $\mathrm{CO}_{2}$ tend to stabilise cordierite at higher- $P$ (Harley, 2008). In spite of these considerations; the simplest explanation of numerous lines of petrological evidence and post-peak $P-T$ vectors is decompression of $<1 \mathrm{kbar}$ with cooling, in the presence of local melt towards the solidus at $\sim 6.5-7.0 \mathrm{kbar}, 950-1000{ }^{\circ} \mathrm{C}$ (Figure 12b).

Garnet $_{2}$ poikiloblasts commonly form aggregates that are rounded and contain numerous quartz inclusions, consistent with crystallization with melt (Waters, 2001). Garnet is stable in adjacent fields down- $T$ from post peak assemblages in garnet absent domains (Figure 6a,b). Thus, domains containing entrained aggregates of euhedral, garnet ${ }_{2}$ poikiloblasts (Figures 2c and 3g) and K-feldspar (e.g. EGB-09-47; domains 3 and 4) are interpreted as relict leucosomes that formed by cooling immediately before crossing the elevated domainal solidi along the retrograde $P-T$ path.

Despite a lack of explicit $P-T$ evidence preceding peak conditions, the presence of

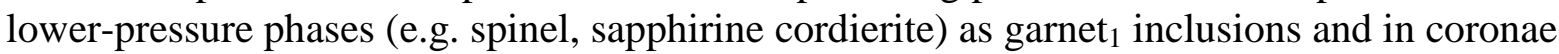
with garnet 2 may be consistent with either a clockwise (Figure 12c(i)) or a counterclockwise (Figure 12c(ii)) $P-T$ evolution. A clockwise $P-T$ path with a high prograde dT/dP gradient

This article is protected by copyright. All rights reserved. 
(Figure 12c(i)) can reach peak conditions of $\sim 7.6 \mathrm{kbar}$ at $\sim 1000{ }^{\circ} \mathrm{C}$ where garnetsapphirine — spinel assemblages are stable (Figure 5c,d), after stabilising garnet — cordierite assemblages on the prograde path. A counterclockwise $P-T$ path (Figure 12 c(ii)) would pass through cordierite, sapphirine and spinel (+ quartz) stability fields at $>900{ }^{\circ} \mathrm{C}$ before forming peritectic garnet at UHT around peak conditions of $\sim 7.6 \mathrm{kbar}$ at $\sim 1000{ }^{\circ} \mathrm{C}$. However, our results do not allow us to discriminate between these alternatives, and the prograde $P-T$ path at Vizianagarma remains unresolved.

\subsection{Timescales of metamorphism}

The petrological evolution of samples EGB-09-45, -47 and -55 is summarized and compared to the inferred $P-T$ path in Figure 13. The spread of concordant SHRIMP zircon ages from $c .1050$ to $c$. 800 Ma likely represents zircon growth from crystallizing melt during this interval, supported by the Ti-in-zircon temperatures almost all of which exceed $880^{\circ} \mathrm{C}$ (Figure 9). Ti-in-zircon temperatures exceed $900{ }^{\circ} \mathrm{C}$ for LA-ICPMS zircon ages in the range c. 1000-880 Ma; the time interval with the most numerous SHRIMP U-Pb zircon ages (see PDFs, Figure 8a). We interpret this data to record a protracted suprasolidus evolution between c. 1050 and $800 \mathrm{Ma}$, where UHT conditions were sustained for a minimum period of $120 \mathrm{Ma}$ between $c .1000$ and $c .900 \mathrm{Ma}$. In the majority of the rock volume, zircon likely crystallized from melt at $c .1000-900 \mathrm{Ma}$ until reaching a $\mathrm{H}_{2} \mathrm{O}$ undersaturated residuum solidus at $>900^{\circ} \mathrm{C}$. An average cooling rate of $0.13 \pm 0.08^{\circ} \mathrm{C} / \mathrm{Ma}$ for the $c .1000-880 \mathrm{Ma}$ duration of UHT metamorphism is derived from a orthogonal regression of the Ti-in-zircon temperatures within error of $900{ }^{\circ} \mathrm{C}$ and the LA-ICPMS ${ }^{238} \mathrm{U} /{ }^{206} \mathrm{~Pb}$ ages and errors (Figure 9a).

There are alternative explanations possible for the spread in near-concordant $\mathrm{U}-\mathrm{Pb}$ zircon ages from $c .1050$ to $c$. $800 \mathrm{Ma}$. First, the ages could represent prolonged crystallization related to periodic melt influx (Harley et al., 2007; Harley \& Nandakumar, 2014; Kelsey, Clark, \& Hand, 2008; Kelsey \& Powell, 2011). Second, one or more Pb-loss episodes could have occurred, leading to analyses within error of Concordia between 1050 and $800 \mathrm{Ma}$ (e.g. Whitehouse, Kamber, \& Moorbath, 1999).

Despite their growth in garnet absent domains, the presence of HREE-depleted, sector-zoned zircon is consistent with equilibration of the growing zircon with garnet and melt, the major repositories of HREE at these $P-T$ conditions. Zircon grains with a spread between equally depleted, or more HREE-enriched signatures occur in garnet ${ }_{1}$ and garnet $_{2}$ bearing domains (Figure 8d). During the post-peak evolution in the interval c. 1000-880 Ma, enrichment of HREE in zircon should occur due to garnet-consuming reactions in those domains that form, for example, orthopyroxene-cordierite intergrowths at the margins of garnet $_{1}$ (Figure 2d) in the presence of melt. However, HREE re-equilibration of zircon with

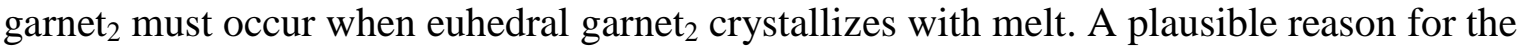
disparity in zircon HREE signatures between garnet absent and garnet bearing assemblages is an interplay between open and closed system behaviour. During the growth of large HREEdepleted zircon in garnet absent domains, the equilibration volume for the zircon-garnet-melt HREE system must be such that zircon throughout the rock volume could equilibrate with garnet and melt. However, during the post-peak evolution involving decompression and garnet breakdown, melt could have been locally isolated if melt volume remained below the melt connectivity threshold. In this scenario, zircon and garnet would only re-equilibrate in garnet bearing domains. Slow incremental growth of sector-zoned zircon in the age range is further diagnostic evidence of zircon growth in crystallizing melt pockets under granulite facies conditions (Figure 7c; Harley, Kelly, \& Möller, 2007; R. J. M. Taylor et al., 2016).

The U-Pb data from zircon rims project onto Concordia between $c .550$ and $500 \mathrm{Ma}$ (Figures 7e,f and 8a,b). A weighted mean age of 511.2 $\pm 6.1 \mathrm{Ma}$ is calculated from three

This article is protected by copyright. All rights reserved. 
concordant dates, suggesting a discrete phase of new zircon growth at this time. The enriched HREE signatures in zircon rims from samples EGB-09-45, 55 reflect the absence of garnet 2 in these samples.

Monazite $\mathrm{U}-\mathrm{Pb}$ ages are interpreted to reflect more-or-less continuous growth between $c$. 950 and $800 \mathrm{Ma}$ in both samples EGB-09-47 and -55. The few concordant PanAfrican ages (c. 550-500 Ma) are not associated with discordant $\mathrm{Pb}$ loss trends. In combination with Ti-in-zircon temperatures of $\sim 810^{\circ} \mathrm{C}$, this provides robust evidence for some, albeit limited, crystallization of monazite and zircon at c. 550-500 Ma.

The process responsible for limited neocrystallization of zircon and monazite at $c$. $550-500 \mathrm{Ma}$ is unclear. Given that the new zircon rims record Ti-in-zircon temperatures in excess of $800^{\circ} \mathrm{C}$ (Figures 7c, 8 and 9), this new growth is unlikely to reflect subsolidus fluidmediated dissolution-reprecipitation (Geisler, Schaltegger, \& Tomaschek, 2007; Harley et al., 2007). There are two plausible alternative processes that could have been responsible for zircon growth at this time: (i) final crystallization of the last vestiges of melt on cooling to the temperature of the elevated (residual) $\mathrm{H}_{2} \mathrm{O}$-undersaturated solidus as part of a protracted metamorphic event lasting in excess of $500 \mathrm{Ma}$; (ii) limited melting due to a minor influx of fluids, with or without any temperature increase. Both processes are consistent with crystallization of sparse biotite laths within leucosome domains in sample EGB-09-47 (Figure 2c). Preserving trapped melt pockets at long lived suprasolidus conditions may seem feasible, given the average cooling rate of $0.13 \pm 0.08^{\circ} \mathrm{C} / \mathrm{Ma}$. However, if melt had remained in these rocks throughout the $c$. 1050-500 Ma tectonothermal history, the occurrence of concordant zircon ages throughout this period might be expected, in contrast with the observed c. 300 Ma gap in the zircon record (Figure 8a,b). The leucosome domains that host the younger zircon contain more $\mathrm{H}_{2} \mathrm{O}$ in the bulk composition ( $\sim 2$ mol.\%) than the (nominally anhydrous) domains with peak mineral assemblages. An influx of $\sim 2$ mol. $\% \mathrm{H}_{2} \mathrm{O}$ shifts the solidus down temperature to between $\sim 800-850^{\circ} \mathrm{C}$ at $6.2 \mathrm{kbar}$ for samples EGB09-45 and -47 (Figure 12b), consistent with Ti-in-zircon temperatures $>800^{\circ} \mathrm{C}$ recorded by the $c$. 550-500 Ma neocrystallized zircon rims. Fluid infiltration into cordierite-bearing granulites commonly results in pinitisation of cordierite. However, at temperatures in excess of $800^{\circ} \mathrm{C}$ cordierite is stable, whereas white mica, a principal constituent of pinite, is not. Thus, a process involving limited influx of $\mathrm{H}_{2} \mathrm{O}$ during the Pan-African event (e.g. Mezger \& Cosca, 1999) is more consistent with observations than retention of residual melt in pockets.

\section{4 | Regional geological context}

In the EGP, the metamorphic evolution of the UHT granulites along the coastal belt differs from those located on the plateau. At Anakapalle, $\sim 60 \mathrm{~km}$ to the southwest along strike from Vizianagaram, based on evidence of $>2$ kbar decompression, a clockwise $P-T$ path has been inferred for UHT granulites (Figure 1; Kelsey et al., 2017; Rickers, Raith, \& Dasgupta, 2001). By contrast, the inferred $P-T$ evolution from several highland localities in the PaderuAnantagiri-Salur block is inferred to have been counterclockwise (Figure 14c; Korhonen, Brown, et al., 2013). However, peak $P-T$ conditions of $\sim 7-8 \mathrm{kbar}$ and $>950^{\circ} \mathrm{C}$ are recorded in both cases. At the highland localities, incremental growth of anatectic zircon occurred from $c .1050$ Ma reaching peak UHT conditions between $c .1000$ and c. 900 Ma (Korhonen, Clark, et al., 2013). However, continuous growth of anatectic zircon until c. $800 \mathrm{Ma}$, as inferred for the rocks at Vizianagaram, has not been recorded at the highland localities. In addition, a Pan-African population of zircon at $c$. 550-500 Ma is most clearly defined at Vizianagaram and at Garbham, another lowland locality (Korhonen et al., 2015).

A correlation between the EGP and Rayner Complex (RC) during the Proterozoic is well documented (Dasgupta et al., 2013; Fitzsimons, 2000; Harley, 2003; Mezger \& Cosca, 1999), and is reflected here in several facets of the zircon geochronology and metamorphic

This article is protected by copyright. All rights reserved. 
evolution. Prolonged growth of concordant zircon between $c .1050$ and $c .800 \mathrm{Ma}$, and suprasolidus granulite facies reworking of the EGP at Vizianagaram at 550-500 Ma is similar to the sequence of events recorded by monazite $\mathrm{U}-\mathrm{Pb}$ ages in the $\mathrm{RC}$ in the Northern Prince Charles Mountains (NPCM; Morrissey, Hand, Kelsey, \& Wade, 2016). Meanwhile, Mesoproterozoic to Neoproterozoic metamorphism and magmatism during the interval 1050$900 \mathrm{Ma}$ is recorded throughout the RC within rocks cropping out along the Mawson Coast (Halpin, Gerakiteys, Clarke, Belousova, \& Griffin, 2005) and from the reworked Archean crust of the Oygarden Group and Stillwell Hills (Halpin et al., 2005; Kelly, Clarke, \& Fanning, 2002). The Beaver Terrane of the Rayner Complex records peak $P-T$ conditions of $\sim 6.0 \mathrm{kbar}$ and $850-900^{\circ} \mathrm{C}$ and post peak near-isobaric cooling (Halpin, White, Clarke, \& Kelsey, 2007; Morrissey, Hand, Kelsey, \& Wade, 2016). However a decompression dominated post-peak history is evident in clockwise evolution through peak $P-T$ conditions of $\sim 8.5 \mathrm{kbar}$ and $900-950^{\circ} \mathrm{C}$, associated with Neoproterozoic reworking of the Oygarden Group and the Stillwell Hills (Halpin, Clarke, White, \& Kelsey, 2007; Halpin, White, Clarke, \& Kelsey, 2007).

Inherited zircon ages in the EGP record a series of concordant clusters and discordant trends associated with ages at $c .1650-1600 \mathrm{Ma}$ and $c .1900-1800 \mathrm{Ma}$ throughout the highland localities (Das et al., 2011; Korhonen et al., 2015; Korhonen, Clark, et al., 2013). Ages between $c .1650-1600$ Ma seemingly coincide with ages for granite and charnockite emplacement in the Ongole Domain (Dharma Rao, Santosh, \& Dong, 2012; Kovach et al., 2001; Simmat \& Raith, 2008). Similar inherited ages from arc-related magmatism (Figure $14 \mathrm{~b}$ ) are found in zircon cores from the RC, with felsic magmatism at c. $1600 \mathrm{Ma}$ in the Oygarden group, and charnockite emplacement at c. 2100-1800 Ma along the Mawson Coast (Halpin et al., 2005) and NPCM (Zhao, Ellis, Kilpatrick, \& McCulloch, 1997).

Interestingly, the granulites from Vizianagaram have inherited concordant zircon with ages of $c$. 2500-2400 Ma, which is seemingly unique to the EGP, but lies within the range of Sm-Nd whole-rock protolith ages of c. 2900-2200 Ma from the EGB (Rickers, Mezger, et al., 2001). These inherited cores could have originated from several adjacent terranes. Granitic magmatism occurred in the Bastar Craton at c. 2500-2450 Ma (Sarkar, Corfu, et al., 1993), which is now adjacent to the Singhbhum and Rengali Provinces at the northern margin of the EGB. Granulite facies metamorphism occurred in the Vestfold Hills terrane at c. 2520$2450 \mathrm{Ma}$ (Clark, Kinny, \& Harley, 2012), which was likely situated around the northern margin of the EGB. Further from the study area, on the other side of the EGP-RC depocentre, c. $2500 \mathrm{Ma}$ detrital zircon in the Ruker Terrane (Phillips, Wilson, Campbell, \& Allen, 2006) and granitoids emplaced in the Lambert Terrane at c. $2400 \mathrm{Ma}$ (Boger, Wilson, \& Fanning, 2001; Mikhalsky, Beliatsky, Sheraton, \& Roland, 2006) are further possibilities for the source of this Archean to Paleoproterozoic detritus.

Despite these potential sources, inheritance of $c$. 2500-2400 Ma is lacking in granulites from the northern EGP (Bose, Das, Torimoto, Arima, \& Dunkley, 2016), a region that is in close proximity to the Rengali Orogen (Bhattacharya et al., 2016; Sawant, Gupta, Clark, \& Misra, 2017), and potentially accessible from the Vestfold, Ruker and Lambert Terranes based on recent Proterozoic plate tectonic reconstructions (Merdith et al., 2017). However, the Archean Napier Complex records a high volume of anatectic zircon growth in the age range $c$. 2500-2400 Ma (Carson, Ague, \& Coath, 2002; Hokada \& Harley, 2004; Horie, Hokada, Hiroi, Motoyoshi, \& Shiraishi, 2012), similar to the neighbouring reworked Archean basement of the Oygarden Group of islands, which also record high-grade recrystallization at $c$. 1000-900 Ma (Halpin et al., 2005; Kelly et al., 2002). In addition, granites were emplaced in the northern Napier Complex c. 2410 Ma (Black, Sheraton, \& James, 1986). This Archean basement was probably closer to the EGP during the Proterozoic (Merdith et al., 2017), and the inherited zircon in this study may have been derived from 
sediment sourced from this crust. If the $c$. 2500-2400 Ma zircon was sourced from the Napier Complex granulites, non-oscillatory, weakly-zoned zircon textures with flattened HREE signatures might be expected (Kelly \& Harley, 2005). However, to properly discriminate between potential sources of inherited zircon in the EGP would require a separate study involving a larger sample size, appropriate textural analysis, higher resolution $\mathrm{U}-\mathrm{Pb}$ zircon geochronology, and determination of REE and Lu-Hf isotopic signatures.

\section{5 | Development of a hot orogen}

A polymetamorphic evolution at UHT conditions has commonly been inferred for the EGP (Dasgupta, 1995; Dasgupta et al., 2013; Rickers, Raith, et al., 2001; Simmat \& Raith, 2008). Many models propose a Grenvillian counterclockwise $P-T$ evolution to an UHT peak at $c$. 1130-930 Ma, followed by near isobaric cooling ('M1') followed by decompression during a separate ('M2') metamorphic event (Das et al., 2011; Dharma Rao, Santosh, \& Chmielowski, 2012; Mohan, Tripathi, \& Motoyoshi, 1997). At Vizianagaram, there is scant evidence for an earlier counterclockwise metamorphic event or for a distribution of concordant $\mathrm{U}-\mathrm{Pb}$ zircon ages to identify multiple separate tectonothermal events. The simplest explanation for the spread of concordant zircon ages from $c$. 1050 to $c$. 800 Ma determined in this study (Figure 8 ) is a single long-lived event in which temperature remained above $\sim 800^{\circ} \mathrm{C}$, appropriate to suprasolidus conditions in most rocks.

Any tectonic model for the evolution of the EGP must explain the UHT metamorphism, the crustal shortening related to the collision of EGP with the Indian craton (Gupta, 2012), and also explain juxtaposition of crustal blocks that experienced contemporaneous decompression and near-isobaric cooling domainated post-peak $P-T$ histories. The granulites at Vizianagaram which record decompression of $<1$ kbar during long-lived cooling from UHT (Figure 10) are separated by $\sim 50 \mathrm{~km}$ from the granulites in the Paderu-Anantagiri-Salur block which record a counterclockwise evolution (Korhonen, Brown, et al., 2013; Korhonen, Clark, et al., 2013; Korhonen et al., 2011). A model of truncated hot orogenesis has previously been suggested to explain the evolution of the region (Korhonen, Brown, et al., 2013; Sizova et al., 2014). These models ascribe metamorphism at UHT and moderate pressures to slab breakoff, crustal extension and replacement of the subcontinental lithospheric mantle with melt-bearing asthenospheric mantle. In these models, counterclockwise $P-T$ paths at UHT conditions could have been produced via renewed shortening, which would return the crust to a 'normal' thickness and allow long-lived nearisobaric cooling (Figure 14b,c). Gupta (2012) has suggested that: 1) the available structural, metamorphic and geochronological evidence supports shortening of the EGP under granulite facies conditions shortly after the Neoproterozoic UHT peak; and, 2) a tectonic contact may exist between the domains experiencing decompression and those recording near-isobaric cooling after a counterclockwise $P-T$ evolution at UHT, with the former being thrust westward over the latter. This model predicts loading with a counterclockwise $P-T$ path in the footwall and exhumation with a decompression dominated $P-T$ path in the hanging wall, consistent with observations (Figure 14c). Furthermore, post-peak decompression could represent partial exhumation via thrusting of hot crust over an adjacent cratonic indentor, such as the Napier Complex (Figure 14b). This possibility is supported by c. 2500-2400 Ma zircon inheritance at Vizianagaram and comparable post-peak $P-T$ paths between Vizianagaram and granulites from western Kemp Land, where post-peak decompression is more pronounced ( 2-5 kbar; Halpin, Clarke, et al., 2007; Harley \& Hensen, 1990; Kelly \& Harley, 2004).

Rickers, Raith, et al. (2001) and Kelsey et al. (2017) have proposed a decompressiondominated $P-T$ path from $>10$ to $\sim 8$ kbar at $>1000^{\circ} \mathrm{C}$ for granulites from Anakapalle $\sim 60 \mathrm{~km}$ to the southwest along strike from Vizianagaram in the Eastern Ghats. Kelsey et al. (2017)

This article is protected by copyright. All rights reserved. 
argued that the decompression could have occurred towards the end of a long-lived counterclockwise $P-T$ loop, an evolution postulated to be typical of the EGP as a whole. Such an evolution would have been characterized by a near uniform $>150^{\circ} \mathrm{C} / \mathrm{kbar}$ prograde apparent geotherm. To account for the lack of evidence elsewhere in the terrane, they argue that the refractory compositions of other $\mathrm{Al}-\mathrm{Mg}$ granulites in the EGP would not have recorded the late-stage decompression. However, this explanation contradicts evidence from UHT localities in other metamorphic belts that garnet-bearing high $\mathrm{Al}-\mathrm{Mg}$ granulites in particular commonly do record post-peak decompression (Harley, 1998). We contend that this is also true for the garnet-bearing high $\mathrm{Al}-\mathrm{Mg}$ granulites from the EGP. If high- $T$ decompression had occurred at the localities studied by Korhonen, Brown, et al. (2013) and Korhonen et al. (2014) it is likely that reaction microstructures involving garnet breakdown would have developed, but these are absent. Mafic rocks at Anakapalle were emplaced at $1580 \mathrm{Ma}$ (Kelsey et al., 2017), far earlier than at many other localities, where emplacement occurred at c. $950 \mathrm{Ma}$ (Korhonen, Clark, et al., 2013). Therefore, a higher apparent thermal gradient [ $>150^{\circ} \mathrm{C} / \mathrm{kbar}$; Korhonen, Brown, et al. (2013)] may have been induced in parts of the EGP during the UHT event by elevated mantle heat flow. Furthermore, in modern collisional belts, rocks exhumed closer to a thrust tend to be exhumed from higher pressures (Harris et al., 2004; Jamieson, Beaumont, Medvedev, \& Nguyen, 2004; Yakymchuk \& Godin, 2012), which may be the case at Anakapalle.

A higher spatial distribution of reliably constrained $P-T$ paths and zircon provenance studies are required to better discriminate between the potential tectonic models, and satisfactorily explain sustained UHT metamorphism for $c$. $100 \mathrm{Ma}$ in thinned crust in the hinterland of a collisional orogen. Possible solutions to this conundrum include prolonged focused radiogenic heat production (Horton et al., 2016), high mantle heat flux, anomalously strengthened residual crust, low erosion rates and/or re-activated convergence at $c .900 \mathrm{Ma}$ (Dasgupta et al., 2013; Mezger \& Cosca, 1999).

Merdith et al. (2017) placed a passive plate margin outboard of the Eastern Ghats/Rayner terrane (EGRT) after subduction/accretion ended at $c .850 \mathrm{Ma}$. This remained a passive margin until the EGRT was within close proximity to the Mawson and South Australian cratons due to subduction from $c .1050$ to $c$. $650 \mathrm{Ma}$ in the Mawson Sea outboard of Australia (Figure 14a). Radiogenic heat production from dominant khondalite and charnockite lithologies were $\sim 3 \mu \mathrm{Wm}^{-3}$ at $550 \mathrm{Ma}$ in the EGP (Kumar, Menon, \& Reddy, 2007). Low erosion rates in the heat producing element (HPE) enriched backarc region of this system could have led to prolonged high- $T$ conditions. Few inherited zircon data in the Prydz orogen are younger than $c .900 \mathrm{Ma}$ (Grew et al., 2012; Hokada, Harley, Dunkley, Kelly, \& Yokoyama, 2016; Kinny, Black, \& Sheraton, 1993; Wang, Liu, Zhao, Zheng, \& Chen, 2016), inhibiting reliable tectonic inferences based on the geochronological data for the period $c$. 900-550 Ma. However maximum detrital zircon ages for passive margins are commonly $>100$ Ma older than sedimentation ages (Cawood, Hawkesworth, \& Dhuime, 2012). These regions are often tectonically stable with low uplift and sedimentation rates induced on the inboard craton, while contemporaneous magmatism is also sparse (Cawood et al., 2012; Cawood \& Nemchin, 2001; Cawood, Nemchin, \& Strachan, 2007). Thus, focused radiogenic heat production over a long period may be the explanation for the long-lived UHT metamorphism in the EGP-RC.

Pan African reworking in the EGP recorded by zircon and monazite was previously interpreted as a mid-amphibolite facies overprint localized along regional scale shear zones or around pegmatites found throughout the EGP (Chatterjee, Das, Bose, Ganguly, \& Hidaka, 2017; Dobmeier \& Raith, 2003; Simmat \& Raith, 2008). Granulite facies conditions $\left(>810^{\circ} \mathrm{C}\right)$ at $c .550-500 \mathrm{Ma}$, as reported in this study based on in-situ Ti-in-zircon thermometry on samples from Vizianagaram, refute these claims. Neosomes in granulites

This article is protected by copyright. All rights reserved. 
from Garbham, to the north of Vizianagaram, similarly contain zircon overgrowths of $c .550$ $\mathrm{Ma}$ age. Additionally, $\mathrm{U}-\mathrm{Pb}$ rutile ages of $c .450 \mathrm{Ma}$ from the EGP record a lower closure temperature $\left(\sim 600^{\circ} \mathrm{C}\right.$ for $100 \mu \mathrm{m}$ grain size) than zircon and monazite (Cherniak, 2000; $\mathrm{R}$. Taylor, Clark, \& Reddy, 2012). Therefore, the inference can be drawn that the EGP terrane had cooled to $\sim 600^{\circ} \mathrm{C}$ by c. $450 \mathrm{Ma}$. Simmat and Raith (2008) reported pronounced hydrous retrogression occurring near shear zones due to fluid flux, but temperatures $>800^{\circ} \mathrm{C}$ are unlikely to be recorded by their mineral assemblages. Pan African zircon and monazite age populations are sparse in southern regions of the EGP.

Preferential reheating may occur in residual granulites that were formed during the 1050-800 Ma granulite facies event, with reworking being determined by the geographic distribution of these residual granulites. The removal of partial melt from the crust leaves dry residual assemblages and removes the buffering effect that partial melting has on crustal heating (Stïwe, 1995). Burial of rocks with high HPE concentrations for $>40$ Ma means HPE are an important heat source. Khondalite and charnockite lithologies in the Eastern Ghats terrane typically produce $\sim 3 \mu \mathrm{Wm}^{-3}$ heat from HPE; a value that is high compared to other Archean and Proterozoic terranes (Kumar, Menon, \& Reddy, 2007). It is feasible that dry, residual rock volumes with high HPE values remained buried at $20 \mathrm{~km}$ after the 1050-800 Ma granulite event (Figure 14), during a period of regional tectonic quiescence until c. 550 $\mathrm{Ma}$ (Li et al., 2008).

The EGRT is placed to the west of a passive margin during the time period until c.550 Ma in some tectonic plate reconstructions (Figure 14a; Merdith et al., 2017). Merdith et al. (2017) suggested that subduction was initiated on the eastern margin of the EGRT by $550 \mathrm{Ma}$ (Figure 14a,b), instigating collision between the EGRT and Australia leading to the development of the Prydz Belt, an orogenic belt traced through the Southern Prince Charles Mountains (Li et al., 2008). It is possible that the Vizianagaram granulites-already residual, HPE enriched and at $\sim 20 \mathrm{~km}$ depth-were in a widened orogenic backarc region inboard of the Prydz orogeny and subject to elevated mantle heat flow to enable minimal reheating to granulite facies conditions (Figure 14). Reworking and melt generation in hot orogens is most likely to occur around regional scale shear zone systems (Perchuk et al., 2016), such as the Nagavali Shear Zone. Reworking of the Vizianagaram granulites at $c .550$ Ma could have been a result of an influx of some $\mathrm{H}_{2} \mathrm{O}$ into the residual granulites, lowering their solidus temperatures to $\sim 800^{\circ} \mathrm{C}$, leading to remelting and neocrystallized zircon rims at these temperatures. Final concordant zircon crystallization at c. $510 \mathrm{Ma}$ (Figure 8b) and U-Pb rutile ages of $c .450 \mathrm{Ma}$ (R. Taylor et al., 2012) are consistent with slow cooling of the EGRT to $\sim 600^{\circ} \mathrm{C}$ in the lower crust in the aftermath of the assembly of Gondwana.

\section{6. | CONCLUSIONS}

1. Granulites at Vizianagaram, Eastern Ghats Province, India, record petrologically robust evidence for suprasolidus zircon crystallization from c. 1050-800 Ma. In-situ Ti-in-zircon thermometry suggests UHT conditions $\left(>900^{\circ} \mathrm{C}\right)$ persisted for a minimum of $c .120$ Ma between $c .1000$ and $c .880$ Ma. Post peak metamorphic conditions are characterized by $<1 \mathrm{kbar}$ of decompression at $\sim 1000^{\circ} \mathrm{C}$ before cooling to $\sim 800^{\circ} \mathrm{C}$. However, the UHT granulites at Vizianagaram may not have followed a conterclockwise $P-T$ path similar to highland localities in the EGP (Korhonen, Brown,Fhpe et al., 2013).

2. Based on Ti-in-zircon thermometry, neocrystallization of zircon and monazite rims at c. 550-510 Ma occurred at $\sim 810^{\circ} \mathrm{C}$. Neocrystallization was likely due to reheating of the Vizianagaram granulites at c. $550 \mathrm{Ma}$ assisted by an influx of $\sim 2 \mathrm{~mol} . \% \mathrm{H}_{2} \mathrm{O}$.

This article is protected by copyright. All rights reserved. 
3. Vizianagaram granulites share events at $c .1050-800$ and $c$. 550-500 Ma with several localities in the Rayner Complex. Sources for inherited c. 2500-2400 Ma zircon populations include the Napier Complex, Ruker Terrane and Bastar Craton.

4. A tectonic model has been proposed for the EGP that accounts for the long-lived juxtaposition of crustal blocks experiencing near-isobaric cooling or decompression dominated post-peak $P-T$ paths at granulite facies conditions. A truncated hot orogen (Korhonen, Brown, et al., 2013; Sizova et al., 2014) may be adequate to generate UHT metamorphism. After crustal thinning, renewed convergence may have led to post-peak decompression, representing partial exhumation via thrusting of hot crust over adjacent granulites with counterclockwise $P-T$ paths and the cratonic indentor.

5. Localised suprasolidus reworking of the EGP occurred in susceptible, preconditioned rocks. Prolonged residence of residual granulites with high HPE concentrations between $c .800$ and $c .550$ Ma preceded the initiation of subduction outboard of the EGRT at c. 550 and formation of the Prydz Belt. Increased mantle heat flow in a widened back-arc comprising the amalgamated EGRT may have preferentially heated susceptible, residual, HPE rich crustal material to suprasolidus $\left(>800^{\circ} \mathrm{C}\right)$ temperatures in proximity to regional shear zone systems.

\section{ACKNOWLEDGEMENTS}

The authors have no conflicts of interests to disclose. The authors also thank K. Merigot and B. McDonald of the John de Laeter Centre for invaluable assistance with TIMA and LA-ICP-MS analyses respectively. RM acknowledges support by a Curtin International Postgraduate Research Scholarship (CIPRS) and an IIT Kharagpur stipend. CC and RT acknowledge support for salaries and analytical work provided by an Australian Research Council (ARC) DECRA award (DE120103067) and the Curtin University Fellowship scheme. This work was partially supported by an ARC Discovery Project (DP160104637) to CC. The authors also thank K. Sajeev and an anonymous reviewer for constructive comments that enabled us to improve this manuscript, and D. Robinson for his thorough editorial handling.

\section{REFERENCES}

Bhattacharya, A., Das, H. H., Bell, E., Bhattacharya, A., Chatterjee, N., Saha, L., \& Dutt, A. (2016). Restoration of Late Neoarchean-Early Cambrian tectonics in the Rengali orogen and its environs (eastern India): The Antarctic connection. Lithos, 263, 190212. doi:10.1016/j.lithos.2016.06.006

Black, L. P., Sheraton, J. W., \& James, P. R. (1986). Late Archaean granites of the Napier Complex, Enderby Land, Antarctica: A comparison of Rb-Sr, Sm-Nd and U-Pb isotopic systematics in a complex terrain. Precambrian Research, 32(4), 343-368. doi:10.1016/0301-9268(86)90036-7

Blereau, E., Johnson, T. E., Clark, C., Taylor, R. J. M., Kinny, P. D., \& Hand, M. (2017). Reappraising the P-T evolution of the Rogaland-Vest Agder Sector, southwestern Norway. Geoscience Frontiers, 8(1), 1-14. doi:10.1016/j.gsf.2016.07.003

Boger, S. D., Hirdes, W., Ferreira, C. A. M., Jenett, T., Dallwig, R., \& Fanning, C. M. (2015). The 580-520Ma Gondwana suture of Madagascar and its continuation into Antarctica and Afric. Gondwana Research, 28(3), 1048-1060. doi:10.1016/j.gr.2014.08.017

This article is protected by copyright. All rights reserved. 
Boger, S. D., Wilson, C. J. L., \& Fanning, C. M. (2001). Early Paleozoic tectonism within the East Antarctic craton: The final suture between east and west Gondwana? Geology, 29(5), 463-466. doi:10.1130/0091-7613(2001)029<0463:EPTWTE>2.0.CO;2

Bose, S., Das, K., Torimoto, J., Arima, M., \& Dunkley, D. J. (2016). Evolution of the Chilka Lake granulite complex, northern Eastern Ghats Belt, India: First evidence of

$\sim 780$ Ma decompression of the deep crust and its implication on the India-Antarctica correlation. Lithos, 263, 161-189. doi:10.1016/j.lithos.2016.01.017

Brown, M. (2007a). Metamorphic conditions in orogenic belts: A record of secular change. International Geology Review, 49(3), 193-234. doi:10.2747/0020-6814.49.3.193

10.1007/s00410-006-0068-5]

Brown, M. (2007b). Metamorphism, Plate Tectonics, and the Supercontinent Cycle. Earth Science Frontiers, 14(1), 1-18. doi:https://doi.org/10.1016/S1872-5791(07)60001-3

Brown, M. (2013). Granite: From genesis to emplacement. GSA bulletin, 123(7-8), 10791113.

Brown, M., \& Johnson, T. E. (2018). Secular change in metamorphism and the onset of global plate tectonics. American Mineralogist. doi:/10.2138/am-2018-6166

Carson, C. J., Ague, J. J., \& Coath, C. D. (2002). U-Pb geochronology from Tonagh Island, East Antarctica: Implications for the timing of ultra-high temperature metamorphism of the Napier Complex. Precambrian Research, 116(3-4), 237-263. doi:10.1016/S0301-9268(02)00023-2

Cawood, P. A., Hawkesworth, C. J., \& Dhuime, B. (2012). Detrital zircon record and tectonic setting. Geology, 40(10), 875-878. doi:10.1130/G32945.1

Cawood, P. A., \& Nemchin, A. A. (2001). Paleogeographic development of the east Laurentian margin: Constraints from $\mathrm{U}-\mathrm{Pb}$ dating of detrital zircons in the Newfoundland Appalachians. Geological Society of America Bulletin, 113(9), 12341246.

Cawood, P. A., Nemchin, A. A., \& Strachan, R. (2007). Provenance record of Laurentian passive-margin strata in the northern Caledonides: Implications for paleodrainage and paleogeography. Bulletin of the Geological Society of America, 119(7-8), 993-1003. doi:10.1130/B26152.1

10.1111/j.1365-3121.2005.00609.x;

Chatterjee, A., Das, K., Bose, S., Ganguly, P., \& Hidaka, H. (2017). Zircon U-Pb SHRIMP and monazite EPMA U-Th-total $\mathrm{Pb}$ geochronology of granulites of the western boundary, Eastern Ghats Belt, India: A new possibility for Neoproterozoic exhumation history Geological Society Special Publication (Vol. 457, pp. 105-140): Geological Society of London.

Cherniak, D. J. (2000). Pb diffusion in rutile. Contributions to Mineralogy and Petrology, 139(2), 198-207. doi:10.1007/PL00007671

Chetty, T. R. K., Vijay, P., Narayana, B. L., \& Giridhar, G. V. (2003). Structure of the Nagavali Shear Zone, Eastern Ghats Mobile Belt, India: Correlation in the East Gondwana reconstruction. Gondwana Research, 6(2), 215-229. doi:10.1016/S1342937X(05)70971-0

Clark, C., Fitzsimons, I. C. W., Healy, D., \& Harley, S. L. (2011). How does the continental crust get really hot? Elements, 7(4), 235-240. doi:10.2113/gselements.7.4.235

Clark, C., Healy, D., Johnson, T., Collins, A. S., Taylor, R. J., Santosh, M., \& Timms, N. E. (2015). Hot orogens and supercontinent amalgamation: A Gondwanan example from southern India. Gondwana Research, 28(4), 1310-1328. doi:10.1016/j.gr.2014.11.005

Clark, C., Kinny, P. D., \& Harley, S. L. (2012). Sedimentary provenance and age of metamorphism of the Vestfold Hills, East Antarctica: Evidence for a piece of Chinese

This article is protected by copyright. All rights reserved. 
Antarctica? Precambrian Research, 196-197, 23-45.

doi:10.1016/j.precamres.2011.11.001

Collins, A. S., Clark, C., \& Plavsa, D. (2014). Peninsular India in Gondwana: The tectonothermal evolution of the Southern Granulite Terrain and its Gondwanan counterparts. Gondwana Research, 25(1), 190-203. doi:10.1016/j.gr.2013.01.002

Collins, A. S., Fitzsimons, I. C. W., Hulscher, B., \& Razakamanana, T. (2003). Structure of the eastern margin of the East African Orogen in central Madagascar. Precambrian Research, 123(2-4), 111-133. doi:10.1016/S0301-9268(03)00064-0

Compston, W., Williams, I., \& Meyer, C. (1984). U-Pb geochronology of zircons from lunar breccia 73217 using a sensitive high mass-resolution ion microprobe. Journal of Geophysical Research: Solid Earth, 89(S02).

Currie, C. A., \& Hyndman, R. D. (2006). The thermal structure of subduction zone backarcs. Journal of Geophysical Research: Solid Earth, 111(B8), n/a-n/a. doi:10.1029/2005JB004024

Das, K., Bose, S., Karmakar, S., Dunkley, D. J., \& Dasgupta, S. (2011). Multiple tectonometamorphic imprints in the lower crust: First evidence of $c .950 \mathrm{Ma}$ (zircon U-Pb SHRIMP) compressional reworking of UHT aluminous granulites from the Eastern Ghats Belt, India. Geological Journal, 46(2-3), 217-239. doi:10.1002/gj.1246

Dasgupta, S. (1995). Pressure-temperature evolutionary history of the Eastern Ghats granulite province: recent advances and some thoughts. Memoirs - Geological Society of India, 34, 101-110.

Dasgupta, S., Bose, S., \& Das, K. (2013). Tectonic evolution of the Eastern Ghats Belt, India. Precambrian Research, 227, 247-258. doi:10.1016/j.precamres.2012.04.005

Dharma Rao, C. V., Santosh, M., \& Chmielowski, R. M. (2012). Sapphirine granulites from Panasapattu, Eastern Ghats belt, India: Ultrahigh-temperature metamorphism in a Proterozoic convergent plate margin. Geoscience Frontiers, 3(1), 9-31. doi:10.1016/j.gsf.2011.09.001

Dharma Rao, C. V., Santosh, M., \& Dong, Y. (2012). U-Pb zircon chronology of the Pangidi-Kondapalle layered intrusion, Eastern Ghats belt, India: Constraints on Mesoproterozoic arc magmatism in a convergent margin setting. Journal of Asian Earth Sciences, 49, 362-375. doi:10.1016/j.jseaes.2011.07.005

10.1016/j.gr.2011.01.007;

Dobmeier, C. J., \& Raith, M. M. (2003). Crustal architecture and evolution of the Eastern Ghats Belt and adjacent regions of India Geological Society Special Publication (Vol. 206, pp. 145-168).

Dorfler, K. M., Caddick, M. J., \& Tracy, R. J. (2015). Thermodynamic modeling of crustal melting using xenolith analogs from the Cortlandt Complex, New York, USA. Journal of Petrology, 56(2), 389-408.

Dragovic, B., Guevara, V. E., Caddick, M. J., Baxter, E. F., \& Kylander-Clark, A. R. C. (2016). A pulse of cryptic granulite-facies metamorphism in the Archean Wyoming Craton revealed by $\mathrm{Sm}-\mathrm{Nd}$ garnet and $\mathrm{U}-\mathrm{Pb}$ monazite geochronology. Precambrian Research, 283, 24-49. doi:10.1016/j.precamres.2016.07.010

Ferry, J. M., \& Watson, E. B. (2007). New thermodynamic models and revised calibrations for the Ti-in-zircon and Zr-in-rutile thermometers. Contributions to Mineralogy and Petrology, 154(4), 429-437. doi:10.1007/s00410-007-0201-0

Fitzsimons, I. C. W. (2000). A review of tectonic events in the east antarctic shield and their implications for gondwana and earlier supercontinents. Journal of African Earth Sciences, 31(1), 3-23. doi:10.1016/S0899-5362(00)00069-5

Foster, G., Kinny, P., Vance, D., Prince, C., \& Harris, N. (2000). The significance of monazite $\mathrm{U}-\mathrm{Th}-\mathrm{Pb}$ age data in metamorphic assemblages; a combined study of

This article is protected by copyright. All rights reserved. 
monazite and garnet chronometry. Earth and Planetary Science Letters, 181(3), 327340.

Fritz, H., Abdelsalam, M., Ali, K. A., Bingen, B., Collins, A. S., Fowler, A. R., . . Viola, G. (2013). Orogen styles in the East African Orogen: A review of the Neoproterozoic to Cambrian tectonic evolution. Journal of African Earth Sciences, 86, 65-106. doi:10.1016/j.jafrearsci.2013.06.004

Galli, A., Le Bayon, B., Schmidt, M. W., Burg, J. P., Caddick, M. J., \& Reusser, E. (2011). Granulites and charnockites of the Gruf Complex: Evidence for Permian ultra-high temperature metamorphism in the Central Alps. Lithos, 124(1-2), 17-45. doi:10.1016/j.lithos.2010.08.003

Geisler, T., Schaltegger, U., \& Tomaschek, F. (2007). Re-equilibration of zircon in aqueous fluids and melts. Elements, 3(1), 43-50.

Grew, E. S., Carson, C. J., Christy, A. G., Maas, R., Yaxley, G. M., Boger, S. D., \& Fanning, C. M. (2012). New constraints from U-Pb, Lu-Hf and Sm-Nd isotopic data on the timing of sedimentation and felsic magmatism in the Larsemann Hills, Prydz Bay, East Antarctic. Precambrian Research, 206, 87-108.

Gupta, S. (2012). Strain localization, granulite formation and geodynamic setting of 'hot orogens': A case study from the Eastern Ghats Province, India. Geological Journal, 47(2-3), 334-351. doi:10.1002/gj.132810.1029/2006TC002005

Hacker, B. R., Gnos, E., Ratschbacher, L., Grove, M., McWilliams, M., Sobolev, S. V., . . $\mathrm{Wu}, \mathrm{Z}$. (2000). Hot and dry deep crustal xenoliths from Tibet. Science, 287(5462), 2463-2466. doi:10.1126/science.287.5462.2463

Hacker, B. R., Ritzwoller, M. H., \& Xie, J. (2014). Partially melted, mica-bearing crust in central tibet. Tectonics, 33(7), 1408-1424. doi:10.1002/2014TC00354510.1029/2009JB007021

Halpin, J. A., Clarke, G. L., White, R. W., \& Kelsey, D. E. (2007). Contrasting P-T-t paths for Neoproterozoic metamorphism in MacRobertson and Kemp Lands, east Antarctic. Journal of Metamorphic Geology, 25(6), 683-701. doi:10.1111/j.15251314.2007.00723.x

Halpin, J. A., Gerakiteys, C., Clarke, G., Belousova, E., \& Griffin, W. (2005). In-situ U-Pb geochronology and Hf isotope analyses of the Rayner Complex, east Antarctic. Contributions to Mineralogy and Petrology, 148(6), 689-706.

Halpin, J. A., White, R. W., Clarke, G. L., \& Kelsey, D. E. (2007). The Proterozoic P-T-t evolution of the Kemp Land Coast, East Antarctica; constraints from Si-saturated and Si-undersaturated metapelites. Journal of Petrology, 48(7), 1321-1349. doi:10.1093/petrology/egm020

Harley, S. L. (1989). The origins of granulites: A metamorphic perspective. Geological Magazine, 126(3), 215-247. doi:10.1017/S0016756800022330

Harley, S. L. (1994). Cordierite as a sensor of fluid and melt distribution in crustal metamorphism. Mineralogical Magazine, 58(1), 374-375.

Harley, S. L. (1998). On the occurrence and characterization of ultrahigh-temperature crustal metamorphism Geological Society Special Publication (Vol. 138, pp. 81-107).

Harley, S. L. (2003). Archaean-Cambrian crustal development of East Antarctica: metamorphic characteristics and tectonic implications. Geological Society, London, Special Publications, 206(1), 203-230.

Harley, S. L. (2008). Refining the P-T records of UHT crustal metamorphism. Journal of Metamorphic Geology, 26(2), 125-154. doi:10.1111/j.1525-1314.2008.00765.x

Harley, S. L. (2016). A matter of time: The importance of the duration of UHT metamorphism. Journal of Mineralogical and Petrological Sciences, 111(2), 50-72. doi:10.2465/jmps.160128

This article is protected by copyright. All rights reserved. 
Harley, S. L., \& Hensen, B. J. (1990). Archaean and Proterozoic high-grade terranes of East Antarctica (40-80 E): a case study of diversity in granulite facies metamorphism High-temperature metamorphism and crustal anatexis (pp. 320-370): Springer.

Harley, S. L., Kelly, N. M., \& Möller, A. (2007). Zircon behaviour and the thermal histories of moutain chains. Elements, 3(1), 25-30. doi:10.2113/gselements.3.1.25

Harley, S. L., \& Nandakumar, V. (2014). Accessory Mineral Behaviour in Granulite Migmatites: a Case Study from the Kerala Khondalite Belt, India. Journal of Petrology, 55(10), 1965-2002.

Harris, N., Caddick, M., Kosler, J., Goswami, S., Vance, D., \& Tindle, A. (2004). The pressure-temperature-time path of migmatites from the Sikkim Himalaya. Journal of Metamorphic Geology, 22(3), 249-264.

Hinthorne, J., Andersen, C., Conrad, R., \& Lovering, J. (1979). Single-grain 207Pb206Pb and $\mathrm{U} / \mathrm{Pb}$ age determinations with a $10-\mu \mathrm{m}$ spatial resolution using the ion microprobe mass analyzer (IMMA). Chemical Geology, 25(4), 271-303.

Hokada, T., \& Harley, S. L. (2004). Zircon growth in UHT leucosome: Constraints from zircon-garnet rare earth elements (REE) relations in Napier Complex, East Antarctic. Journal of Mineralogical and Petrological Sciences, 99(4), 180-190. doi:10.2465/jmps.99.180

Hokada, T., Harley, S. L., Dunkley, D. J., Kelly, N. M., \& Yokoyama, K. (2016). Peak and post-peak development of UHT metamorphism at Mather Peninsula, Rauer Islands: Zircon and monazite U-Th-Pb and REE chemistry constraints. Journal of Mineralogical and Petrological Sciences, 111(2), 89-103. doi:10.2465/jmps.150829

Holder, R.M., Hacker, B.R., Horton, F., \& Rakotondrazafy, A.F.M., 2018. Ultrahigh- temperature osumilite gneisses in southern Madagascar record combined heat advection and high rates of radiogenic heat production in a long- lived high- $\mathrm{T}$ orogeny. Journal of Metamorphic Geology, 36(7), 855-880.

Holland, T. J. B., \& Powell, R. (2011). An improved and extended internally consistent thermodynamic dataset for phases of petrological interest, involving a new equation of state for solids. Journal of Metamorphic Geology, 29(3), 333-383. doi:10.1111/j.1525-1314.2010.00923.X

Horie, K., Hokada, T., Hiroi, Y., Motoyoshi, Y., \& Shiraishi, K. (2012). Contrasting Archaean crustal records in western part of the Napier Complex, East Antarctica: New constraints from SHRIMP geochronology. Gondwana Research, 21(4), 829-837. doi:10.1016/j.gr.2011.08.013

Horton, F., Hacker, B., Kylander-Clark, A., Holder, R., \& Jöns, N. (2016). Focused radiogenic heating of middle crust caused ultrahigh temperatures in southern Madagascar. Tectonics, 35(2), 293-314. doi:10.1002/2015TC004040

Hyndman, R. D. (2015). Tectonic consequences of a uniformly hot backarc and why is the cordilleran mountain belt high? Geoscience Canada, 42(4), 383-402. doi:10.12789/geocanj.2015.42.078

Hyndman, R. D., \& Currie, C. A. (2011). Why is the North America Cordillera high? Hot backarcs, thermal isostasy, and mountain belts. Geology, 39(8), 783-786. doi:10.1130/G31998.1

Jamieson, R. A., \& Beaumont, C. (2011). Coeval thrusting and extension during lower crustal ductile flow - implications for exhumation of high-grade metamorphic rocks. Journal of Metamorphic Geology, 29(1), 33-51. doi:10.1111/j.1525-1314.2010.00908.x

Jamieson, R. A., Beaumont, C., Medvedev, S., \& Nguyen, M. H. (2004). Crustal channel flows: 2. Numerical models with implications for metamorphism in the HimalayanTibetan orogen. Journal of Geophysical Research B: Solid Earth, 109(6), B06407 06401-06424. doi:10.1029/2003JB002811

This article is protected by copyright. All rights reserved. 
Jamieson, R. A., Beaumont, C., Warren, C. J., \& Nguyen, M. H. (2010). The Grenville Orogen explained? Applications and limitations of integrating numerical models with geological and geophysical data. Canadian Journal of Earth Sciences, 47(4), 517-539. doi:10.1139/E09-070

Johnson, T. E., White, R. W., \& Powell, R. (2008). Partial melting of metagreywacke: a calculated mineral equilibria study. Journal of Metamorphic Geology, 26(8), 837-853.

Johnson, T., Brown, M., \& White, R. (2010). Petrogenetic modelling of strongly residual metapelitic xenoliths within the southern Platreef, Bushveld Complex, South Afric. Journal of Metamorphic Geology, 28(3), 269-291.

Kamineni, D. C., \& Rao, A. T. (1988). Sapphirine-Bearing Quartzite from the Eastern Ghats Granulite Terrain, Vizianagaram, India. The Journal of Geology, 96(2), 209-220. doi:10.1086/629210

Kelly, N. M., Clarke, G. L., \& Fanning, C. M. (2002). A two-stage evolution of the Neoproterozoic Rayner Structural Episode: New U-Pb sensitive high resolution ion microprobe constraints from the Oygarden Group, Kemp Land, East Antarctic. Precambrian Research, 116(3-4), 307-330. doi:10.1016/S0301-9268(02)00028-1

Kelly, N. M., \& Harley, S. L. (2004). Orthopyroxene-corundum in Mg-Al-rich granulites from the Oygarden islands, East Antarctic. Journal of Petrology, 45(7), 1481-1512. doi:10.1093/petrology/egh023

Kelly, N. M., \& Harley, S. L. (2005). An integrated microtextural and chemical approach to zircon geochronology: Refining the Archaean history of the Napier Complex, east Antarctic. Contributions to Mineralogy and Petrology, 149(1), 57-84. doi:10.1007/s00410-004-0635-6

Kelsey, D. E. (2008). On ultrahigh-temperature crustal metamorphism. Gondwana Research, 13(1), 1-29. doi:10.1016/j.gr.2007.06.001

Kelsey, D. E., Clark, C., \& Hand, M. (2008). Thermobarometric modelling of zircon and monazite growth in melt-bearing systems: Examples using model metapelitic and metapsammitic granulites. Journal of Metamorphic Geology, 26(2), 199-212. doi:10.1111/j.1525-1314.2007.00757.x

Kelsey, D. E., \& Hand, M. (2015). On ultrahigh temperature crustal metamorphism: Phase equilibria, trace element thermometry, bulk composition, heat sources, timescales and tectonic settings. Geoscience Frontiers, 6(3), 311-356. doi:10.1016/j.gsf.2014.09.006

Kelsey, D. E., Morrissey, L. J., Hand, M., Clark, C., Tamblyn, R., Gaehl, A. A., \& Marshall, S. (2017). Significance of post-peak metamorphic reaction microstructures in the ultrahigh temperature Eastern Ghats Province, India. Journal of Metamorphic Geology, 35(9), 1081-1109. doi:10.1111/jmg.12277

Kelsey, D. E., \& Powell, R. (2011). Progress in linking accessory mineral growth and breakdown to major mineral evolution in metamorphic rocks: A thermodynamic approach in the $\mathrm{Na}_{2} \mathrm{O}-\mathrm{CaO}-\mathrm{K}_{2} \mathrm{O}-\mathrm{FeO}-\mathrm{MgO}-\mathrm{Al}_{2} \mathrm{O}_{3}-\mathrm{SiO}_{2}-\mathrm{H}_{2} \mathrm{O}-\mathrm{TiO}_{2}-\mathrm{ZrO}_{2}$ system. Journal of Metamorphic Geology, 29(1), 151-166. doi:10.1111/j.15251314.2010.00910.x

Kinny, P. D., Black, L. P., \& Sheraton, J. W. (1993). Zircon ages and the distribution of Archaean and Proterozoic rocks in the Rauer Islands. Antarctic Science, 5(2), $193-$ 206.

Korhonen, F. J., Brown, M., Clark, C., \& Bhattacharya, S. (2013). Osumilite-melt interactions in ultrahigh temperature granulites: Phase equilibria modelling and implications for the P-T-t evolution of the eastern ghats province, india. Journal of Metamorphic Geology, 31(8), 881-907. doi:10.1111/jmg.12049

Korhonen, F. J., Brown, M., Clark, C., Foden, J. D., \& Taylor, R. (2015). Are granites and granulites consanguineous? Geology, 43(11), 991-994. doi:10.1130/G37164.1

This article is protected by copyright. All rights reserved. 
Korhonen, F. J., Clark, C., Brown, M., Bhattacharya, S., \& Taylor, R. (2013). How long-lived is ultrahigh temperature (UHT) metamorphism? Constraints from zircon and monazite geochronology in the Eastern Ghats orogenic belt, India. Precambrian Research, 234, 322-350. doi:10.1016/j.precamres.2012.12.001

Korhonen, F. J., Clark, C., Brown, M., \& Taylor, R. J. M. (2014). Taking the temperature of Earth's hottest crust. Earth and Planetary Science Letters, 408, 341-354. doi:10.1016/j.eps1.2014.10.028

Korhonen, F. J., Saw, A. K., Clark, C., Brown, M., \& Bhattacharya, S. (2011). New constraints on UHT metamorphism in the Eastern Ghats Province through the application of phase equilibria modelling and in situ geochronology. Gondwana Research, 20(4), 764-781. doi:10.1016/j.gr.2011.05.006

Kovach, V. P., Simmat, R., Rickers, K., Berezhnaya, N. G., Salnikova, E. B., Dobmeier, C., . .. Kotov, A. B. (2001). The Western Charnockite Zone of the Eastern Ghats Belt, India - An Independent Crustal Province of Late Archaean $(2.8 \mathrm{Ga})$ and Palaeoproterozoic (1.7-1.6 Ga) Terrains. Gondwana Research, 4(4), 666-667. doi:10.1016/S1342-937X(05)70462-7

Krystek, M. \& Anton, M. (2007) A weighted total least-squares algorithm for fitting a straight line. Measurement Science and Technology, 18(11), 3438-3433.

Kumar, P. S., Menon, R., \& Reddy, G. K. (2007). The role of radiogenic heat production in the thermal evolution of a Proterozoic granulite-facies orogenic belt: Eastern Ghats, Indian Shield. Earth and Planetary Science Letters, 254(1-2), 39-54. doi:10.1016/j.epsl.2006.11.018

Li, Z.-X., Bogdanova, S., Collins, A., Davidson, A., De Waele, B., Ernst, R., . . Jacobs, J. (2008). Assembly, configuration, and break-up history of Rodinia: a synthesis. Precambrian Research, 160(1-2), 179-210.

Liu, Y., Hu, Z., Zong, K., Gao, C., Gao, S., Xu, J., \& Chen, H. (2010). Reappraisement and refinement of zircon $\mathrm{U}-\mathrm{Pb}$ isotope and trace element analyses by LA-ICP-MS. Chinese Science Bulletin, 55(15), 1535-1546.

Mahato, S., Bhattacharya, A. (2010). P-T conditions of the cratonic rocks and Eastern Ghats granulites along the Eastern Ghats Frontal Thrust, Jeypore (Orissa), India. Journal of Asian Earth Sciences, 39(6), 537-550.

McKenzie, D., \& Priestley, K. (2008). The influence of lithospheric thickness variations on continental evolution. Lithos, 102(1-2), 1-11. doi:10.1016/j.lithos.2007.05.005

Merdith, A. S., Collins, A. S., Williams, S. E., Pisarevsky, S., Foden, J. D., Archibald, D. B., .. . Plavsa, D. (2017). A full-plate global reconstruction of the Neoproterozoic. Gondwana Research, 50, 84-134.

Mezger, K., \& Cosca, M. A. (1999). The thermal history of the Eastern Ghats Belt (India) as revealed by $\mathrm{U}-\mathrm{Pb}$ and $40 \mathrm{Ar} / 39 \mathrm{Ar}$ dating of metamorphic and magmatic minerals: Implications for the SWEAT correlation. Precambrian Research, 94(3-4), 251-271. doi:10.1016/S0301-9268(98)00118-1

Mikhalsky, E. V., Beliatsky, B. V., Sheraton, J. W., \& Roland, N. W. (2006). Two distinct Precambrian terranes in the Southern Prince Charles Mountains, East Antarctica: SHRIMP dating and geochemical constraints. Gondwana Research, 9(3), 291-309. doi:10.1016/j.gr.2005.10.002

Mohan, A., Tripathi, P., \& Motoyoshi, Y. (1997). Reaction history of sapphirine granulites and a decompressional P-T path in a granulite complex from the Eastern Ghats. Proceedings of the Indian Academy of Sciences, Earth and Planetary Sciences, 106(3), 115-129.

Morrissey, L. J., Hand, M., Kelsey, D. E., \& Wade, B. P. (2016). Cambrian high-temperature reworking of the Rayner-Eastern ghats terrane: Constraints from the Northern Prince

This article is protected by copyright. All rights reserved. 
Charles Mountains region, East Antarctic. Journal of Petrology, 57(1), 53-91. doi:10.1093/petrology/egv082

Nanda, J., Gupta, S., \& Hacker, B. (2018). U-Pb zircon and titanite ages from granulites of the Koraput area - Evidence for Columbia, Rodinia and gondwana from the Eastern Ghats Province, India. Lithos 314, 394-413

Nasdala, L., Zhang, M., Kempe, U., Panczer, G., Gaft, M., Andrut, M., \& Plötze, M. (2003). Spectroscopic methods applied to zircon. Reviews in Mineralogy and Geochemistry, 53(1), 427-467.

Paton, C., Hellstrom, J., Paul, B., Woodhead, J., \& Hergt, J. (2011). Iolite: Freeware for the visualisation and processing of mass spectrometric data. Journal of Analytical Atomic Spectrometry, 26(12), 2508-2518.

Perchuk, A., Safonov, O., Smit, C., Van Reenen, D., Zakharov, V., \& Gerya, T. (2016). Precambrian ultra-hot orogenic factory: Making and reworking of continental crust. Tectonophysics.

Phillips, G., Wilson, C. J., Campbell, I., \& Allen, C. M. (2006). U-Th-Pb detrital zircon geochronology from the southern Prince Charles mountains, east Antarcticadefining the Archaean to Neoproterozoic Ruker province. Precambrian Research, 148(3-4), 292-306.

Plavsa, D., Collins, A. S., Foden, J. D., \& Clark, C. (2015). The evolution of a Gondwanan collisional orogen: A structural and geochronological appraisal from the Southern Granulite Terrane, South India. Tectonics, 34(5), 820-857. doi:10.1002/2014TC003706

Powell, R., \& Holland, T. J. B. (2008). On thermobarometry. Journal of Metamorphic Geology, 26(2), 155-179. doi:10.1111/j.1525-1314.2007.00756.x

Pownall, J. M. (2015). UHT metamorphism on Seram, eastern Indonesia: Reaction microstructures and P-T evolution of spinel-bearing garnet-sillimanite granulites from the Kobipoto Complex. Journal of Metamorphic Geology, 33(9), 909-935. doi:10.1111/jmg. 12153

Prakash, D., Singh, P. C., Singh, C. K., Tewari, S., Arima, M., \& Frimmel, H. E. (2015). Reaction textures and metamorphic evolution of sapphirine-spinel-bearing and associated granulites from Diguva Sonaba, Eastern Ghats Mobile Belt, India. Geological Magazine, 152(2), 316-340. doi:10.1017/S0016756814000399

Rickers, K., Mezger, K., \& Raith, M. M. (2001). Evolution of the continental crust in the Proterozoic Eastern Ghats Belt, India and new constraints for Rodinia reconstruction: Implications from $\mathrm{Sm}-\mathrm{Nd}, \mathrm{Rb}-\mathrm{Sr}$ and $\mathrm{Pb}-\mathrm{Pb}$ isotopes. Precambrian Research, 112(34), 183-210. doi:10.1016/S0301-9268(01)00146-2

Rickers, K., Raith, M., \& Dasgupta, S. (2001). Multistage reaction textures in xenolithic high-MgAl granulites at Anakapalle, Eastern Ghats Belt, India: Examples of contact polymetamorphism and infiltration-driven metasomatism. Journal of Metamorphic Geology, 19(5), 561-580. doi:10.1046/j.0263-4929.2001.00329.x

Rubatto, D., \& Gebauer, D. (2000). Use of cathodoluminescence for U-Pb zircon dating by ion microprobe: some examples from the Western Alps Cathodoluminescence in geosciences (pp. 373-400): Springer.

Rushmer, T. (1991). Partial melting of two amphibolites: contrasting experimental results under fluid-absent conditions. Contributions to Mineralogy and Petrology, 107(1), 41-59.

Sarkar, G., Corfu, F., Paul, D. K., McNaughton, N. J., Gupta, S. N., Bishui, P. K. (1993). Early Archean crust in Bastar Craton, Central India - a geochemical and isotopic study. Precambrian Research, 62(1-2), 127-137.

This article is protected by copyright. All rights reserved. 
Sarkar, S., Dasgupta, S., \& Fukuoka, M. (2003). Petrological evolution of a suite of spinel granulites from Vizianagram, Eastern Ghats Belt, India, and genesis of sapphirinebearing assemblages. Journal of Metamorphic Geology, 21(9), 899-913. doi:10.1046/j.1525-1314.2003.00490.x

Sarkar, T., \& Schenk, V. (2016). Early Mesoproterozoic (1.6-1.5 Ga) granulite facies events in the Ongole domain: geodynamic significance and global correlation. Journal of Metamorphic Geology, 34(8), 765-784. doi:10.1111/jmg.12207

Simmat, R., \& Raith, M. M. (2008). U-Th-Pb monazite geochronometry of the Eastern Ghats Belt, India: Timing and spatial disposition of poly-metamorphism. Precambrian Research, 162(1-2), 16-39. doi:10.1016/j.precamres.2007.07.016

Sawant, A. D., Gupta, S., Clark, C., Misra, S. (2017). The Rauer-Rengali connection in the Indo-Antarctica amalgam: evidence from structure, metamorphism and geochronology. Geological Society, London, Special Publications, 457, https://doi.org/10.1144/SP457.9

Sizova, E., Gerya, T., \& Brown, M. (2014). Contrasting styles of Phanerozoic and Precambrian continental collision. Gondwana Research, 25(2), 522-545. doi:10.1016/j.gr.2012.12.011

Stacey, J. S., \& Kramers, J. D. (1975). Approximation of terrestrial lead isotope evolution by a two-stage model. Earth and Planetary Science Letters, 26(2), 207-221.

Stern, R. A. (2001). A new isotopic and trace-element standard for the ion microprobe: preliminary thermal ionization mass spectrometry (TIMS) $U-P b$ and electronmicroprobe data: Ressources naturelles Canada.

Stüwe, K. (1995). Thermal buffering effects at the solidus. Implications for the equilibration of partially melted metamorphic rocks. Tectonophysics, 248(1-2), 39-51.

Taylor, R., Clark, C., \& Reddy, S. M. (2012). The effect of grain orientation on secondary ion mass spectrometry (SIMS) analysis of rutile. Chemical Geology, 300-301, 81-87. doi:10.1016/j.chemgeo.2012.01.013

Taylor, R. J. M., Kirkland, C. L., \& Clark, C. (2016). Accessories after the facts: Constraining the timing, duration and conditions of high-temperature metamorphic processes. Lithos, 264, 239-257. doi:10.1016/j.lithos.2016.09.004

Thompson J. B. (1957). The graphical analysis of mineral assemblages in pelitic schists. Am. Mineral., 42, 842-858.

Thompson, P., Harley, S. L., \& Carrington, D. P. (2001). The distribution of $\mathrm{H}_{2} \mathrm{O}-\mathrm{CO}_{2}$ between cordierite and granitic melt under fluid-saturated conditions at $5 \mathrm{kbar}$ and $900{ }^{\circ}$ C. Contributions to Mineralogy and Petrology, 142(1), 107-118.

Upadhyay, D., Gerdes, A., \& Raith, M. M. (2009). Unraveling sedimentary provenance and tectonothermal history of high-temperature metapelites, using zircon and monazite chemistry: A case study from the eastern ghats belt, India. Journal of Geology, 117(6), 665-683. doi:10.1086/606036

Wang, W., Liu, X., Zhao, Y., Zheng, G., \& Chen, L. (2016). U-Pb zircon ages and Hf isotopic compositions of metasedimentary rocks from the Grove Subglacial Highlands, East Antarctica: Constraints on the provenance of protoliths and timing of sedimentation and metamorphism. Precambrian Research, 275, 135-150. doi:10.1016/j.precamres.2015.12.018

Waters, D. J. (2001). The significance of prograde and retrograde quartz-bearing intergrowth microstructures in partially melted granulite-facies rocks. Lithos, 56(1), 108-110.

Wheller, C. J., \& Powell, R. (2014). A new thermodynamic model for sapphirine: Calculated phase equilibria in $\mathrm{K}_{2} \mathrm{O}-\mathrm{FeO}-\mathrm{MgO}-\mathrm{Al}_{2} \mathrm{O}_{3}-\mathrm{SiO}_{2}-\mathrm{H}_{2} \mathrm{O}-\mathrm{TiO}_{2}-\mathrm{Fe}_{2} \mathrm{O}_{3}$. Journal of Metamorphic Geology, 32(3), 287-299. doi:10.1111/jmg.12067

This article is protected by copyright. All rights reserved. 
White, R. W., \& Powell, R. (2002). Melt loss and the preservation of granulite facies mineral assemblages. Journal of Metamorphic Geology, 20(7), 621-632. doi:10.1046/j.15251314.2002.00206.x

White, R. W., \& Powell, R. (2010). Retrograde melt-residue interaction and the formation of near-anhydrous leucosomes in migmatites. Journal of Metamorphic Geology, 28(6), 579-597. doi:10.1111/j.1525-1314.2010.00881.x

White, R. W., Powell, R., \& Clarke, G. L. (2002). The interpretation of reaction textures in Fe-rich metapelitic granulites of the Musgrave Block, central Australia: constraints from mineral equilibria calculations in the system $\mathrm{K}_{2} \mathrm{O}-\mathrm{FeO}-\mathrm{MgO}-\mathrm{Al}_{2} \mathrm{O}_{3}-\mathrm{SiO}_{2}-\mathrm{H}_{2} \mathrm{O}-$ $\mathrm{TiO}_{2}-\mathrm{Fe}_{2} \mathrm{O}_{3}$. Journal of Metamorphic Geology, 20(1), 41-55.

White, R. W., Powell, R., Holland, T. J. B., Johnson, T. E., \& Green, E. C. R. (2014). New mineral activity-composition relations for thermodynamic calculations in metapelitic systems. Journal of Metamorphic Geology, 32(3), 261-286. doi:10.1111/jmg. 12071

Whitehouse, M. J., Kamber, B. S., Moorbath, S. (1999). Age significance of U-Th-Pb zircon data from early Archaean rocks of west Greenland - a reassessment based on combined ion-microprobe and imaging studies. Chemical Geology, 160(3), 201-224.

Whitney, D. L., \& Evans, B. W. (2010). Abbreviations for names of rock-forming minerals. American Mineralogist, 95(1), 185-187. doi:10.2138/am.2010.3371

Wiedenbeck, M., Alle, P., Corfu, F., Griffin, W., Meier, M., Oberli, F. v., . . . Spiegel, W. (1995). Three natural zircon standards for U-Th-Pb, Lu-Hf, trace element and REE analyses. Geostandards and Geoanalytical Research, 19(1), 1-23.

Yakymchuk, C., \& Godin, L. (2012). Coupled role of deformation and metamorphism in the construction of inverted metamorphic sequences: an example from far-northwest Nepal. Journal of Metamorphic Geology, 30(5), 513-535.

Zhao, J. X., Ellis, D. J., Kilpatrick, J. A., \& McCulloch, M. T. (1997). Geochemical and Sr$\mathrm{Nd}$ isotopic study of charnockites and related rocks in the northern Prince Charles Mountains, East Antarctica: Implications for charnockite petrogenesis and proterozoic crustal evolution. Precambrian Research, 81(1-2), 37-66.

\section{Supporting information}

\section{Appendix S1}

Analytical protocol for phase mapping using the TESCAN TIMA FEG-SEM.

\section{Figure S1}

Images and analysis spots for zircon (CL) grains in samples EGB-09-45, -57 and -55 analysed by SHRIMP. Data points given in Table S2.

\section{Figure S2}

Images and analysis spots for monazite (BSE) grains in samples EGB-09-45, -57 and -55 analyzed by SHRIMP. Data points given in Table S2.

\section{Figure S3}

Full annotated $P-T$ pseudosections calculated using THERMOCALC 3.40 for samples EGB09-45 and -47 calculated using XRF whole rock compositions.

\section{Figure S4}

Full annotated $P-T$ pseudosections calculated using THERMOCALC 3.40 for domains 1 and 2 (Figure 4a) from sample EGB-09-45. 


\section{Figure S5}

Full annotated $P-T$ pseudosections calculated using THERMOCALC 3.40 for domains $1-4$ (Figure 4b) from sample EGB-09-47.

\section{Table S1}

EPMA major element analysis for main phases in samples EGB-09-45, -47.

\section{Table S2}

SIMS Cordierite volatile analyses for samples EGB-09-45 and -47.

\section{Table S3}

Raw data tables for SHRIMP zircon and monazite analyses.

\section{Table S4}

Raw U-Pb data tables for LA-ICP-MS zircon analyses.

\section{Table S5}

Raw REE and Ti data tables for LA-ICP-MS zircon analyses.

\section{Figure captions}

FIGURE 1 (a) Map of the Eastern Ghats Mobile Belt (EGMB) to show domains defined by different characteristic lithologies (after Rickers et al., 2001; Korhonen, Clark et al., 2013). The samples were

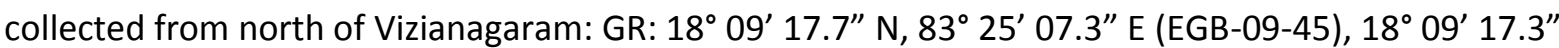

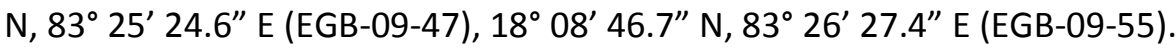

FIGURE 2 Plane polarized light photomicrographs of samples EGB-09-45 (a, b) and EGB-09-47 (c-i); scale bars are $500 \mu \mathrm{m}$. (a) Grt and sill porphyroblasts with adjacent crd-qz intergrowths in $\mathrm{kfs}+\mathrm{qz}$ matrix. (b) Opx-sil-spl intergrowths; thin seams of crd separate opx and sil. (c) Grt ${ }_{1}$ with spr inclusions wrapped by fine-grained sil-crd-qz intergrowths. Euhedral grt $_{2}$ occurs with coarse bt laths and kfs. (d) Crd, rt and qz inclusions in grt ${ }_{1}$. (e) Spl inclusions in grt $_{1}$. (f) $\mathrm{Grt}_{1}$ in contact with prismatic sil and opx, mantled by crd and grt 2 .

FIGURE 3 Plane polarized light photomicrographs of sample EGB-09-47. (a) Grt ${ }_{1}$ porphyroblasts mantled by opx-sil intergrowth (NB opx and sil now separated by crd). (b) Domains in EGB-09-47: $\mathrm{grt}_{2}-\mathrm{ilm}-\mathrm{kfs}$, finer grained sil-crd-qz, coarser opx-sil intergrowths. (c) Rare spr-spl mantled by sil. Opx-sil intergrowths, in which opx and sil are separated by crd; NB large zrc grain shown in Fig 6c. (d) Spl with spr|sil|grt|qz corona. (e) Ilm with sil|grt|qz corona. (f) Setting of opx|crd|sil coronae. (g) Setting of grt $_{2}-\mathrm{kfs}$ relict leucosomes, grt $_{1}$, and spl|sil|grt corona; NB distinctive euhedral habit of grt $_{2}$. (h) Porphyroblastic crd, grain diameter $>500 \mu \mathrm{m}$, in contact with opx. NB retrograde crd seam between opx and sill to the left of the figure for comparison.

This article is protected by copyright. All rights reserved. 
FIGURE 4 Tescan Integrated Mineral Analyser (TIMA) mineral maps for samples EGB-09-45 and -47 with petrological domains used for phase equilibrium modelling outlined. Compositions were calculated from mineral abundances (Table 1) for each area shown (Table 2).

FIGURE 5 Simplified $P-T$ phase diagrams for domains 1 (a) and 2 (b) for sample EGB-09-45. Fully labelled $P-T$ phase diagrams are given in Figure $S 4$. Interpreted peak (red) and retrograde (blue) stability fields for each domain are outlined by dashed lines that include the $2 \sigma$ uncertainties on the peak and retrograde fields. Black arrows connect peak and retrograde fields, across the solidus, and indicate the simplest post peak $P-T$ vector in each case

FIGURE 6 Simplified P-T phase diagrams for domains 1 (a), 2 (b), 3 (c) and 4 (d) for sample EGB-0947. Fully labelled $P-T$ phase diagrams are given in Figure $S 5$. Interpreted peak (red) and retrograde (blue) stability fields for each domain are outlined by dashed lines that include the $2 \sigma$ uncertainties on the peak and retrograde fields. Black arrows connect peak and retrograde fields, across the solidus, and indicate the simplest post peak $P-T$ vector in each case.

FIGURE 7 Cathodoluminescence (CL) images of representative zircon morphologies in EGB-09-45 (e), -47 (b, c , d) and -55 (a, f). In-situ LA-ICP-MS analysis spots highlighted: green - U-Pb age (Ma, discordant analyses scored); red, Ti-in-zircon temperature $\left({ }^{\circ} \mathrm{C}\right)$. (a) Bright $\mathrm{CL}$ sector zoned core with dark $\mathrm{CL}$ sector zoned overgrowths. (b) Zircon with a soccer ball morphology. (c) Large, high CL resoponse, sector zoned zircon. (d) Coarse sector zoned grain in ilm/sil |grt/qz corona. (e, f) Grains with convolute zoning in cores and bright $\mathrm{CL}$ rims.

FIGURE 8 (a) Tera-Wasseberg plot of LA-ICP-MS and SHRIMP U-Pb isotope ratios for all analysed spots on zircon from samples EGB-09-45, -47 and -55 . Probability density functions for ${ }^{207} \mathrm{~Pb} /{ }^{206} \mathrm{~Pb}$ and ${ }^{238} \mathrm{U} /{ }^{206} \mathrm{~Pb}$ are also shown. The data shown in figure (b) are outlined by the box. (b) TeraWasseberg plot of LA-ICP-MS and SHRIMP U-Pb isotope ratios for Neoproterozoic-Cambrian zircon data from samples EGB-09-45, -47 and -55 . Note the gap in concordant SHRIMP data in the interval 800-550 Ma, and Concordia age of 511.2 $\pm 6.1 \mathrm{Ma}$. (c) Tera-Wasseberg plot of LA-ICP-MS U-Pb isotope ratios for zircon from EGB-09-45, -47 and -55 , with error ellipses shaded for Ti-in-zircon temperature. (d) Chondrite-normalised rare earth element plot for zircon in EGB-09-47. Dark lines indicate grains in garnet-absent domains, whereas the dotted lines represent grains in garnet bearing domains.

FIGURE 9 Temperature-age plots for LA-ICP-MS data for EGB-09-45, -47 and -55. (a) Solid ellipses are LA-ICP-MS data from the age ranges of concordant SHRIMP data (see Figure 7). Dashed ellipses are analyses in the age range of discordant SHRIMP analyses; the red line indicates the regression line for average cooling rate $\left(0.13 \pm 0.08^{\circ} \mathrm{C} / \mathrm{Ma}\right)$, during $\mathrm{UHT}$, with the minimum and maximum

This article is protected by copyright. All rights reserved. 
shown with grey dashed lines. (b) Temperature-age plot labelled with textural features seen in CL images of zircon. Probability Density Functions (PDFs) emphasize the population of zircon with crystallization temperatures around $900 \stackrel{\circ}{ } \mathrm{C}$ between $c .1000$ and $880 \mathrm{Ma}$, and a second population of zircon with crystallization temperatures around $810^{\circ} \mathrm{C}$ at c. 550-500 Ma.

FIGURE 10 Backscatter electron (BSE) images of monazite to show the typical morphology of grains from EGB-09-47 and -55, including SHRIMP analysis spots (ages in Ma).

FIGURE 11 Tera-Wasserberg plot of SHRIMP U-Pb monazite data from samples EGB-09-47 and -55.

FIGURE 12 (a) $P-T$ plot of peak (red) and retrograde (blue) stability fields ( $+\mathrm{kfs}$, qz, ilm $\pm \mathrm{rt}$ ) from various domains in EGB-09-45 and -47 (see Figures 4, 5 and 6). (b) Domainal near peak (red) and whole-rock retrograde (blue) solidi. Black arrows indicate the simplest post peak $P-T$ vector for domains 45-1, 45-2, 47-2 and 47-4. The overall inferred $P-T$ trajectory is marked with a grey arrow. C) Inferred $P-T$ paths for this study (grey), Korhonen et al. (2013) (red) and Kelsey et al. (2017) (blue). (i) A potential prograde path for a clockwise $P-T$ evolution. (ii) A potential prograde path for a counterclockwise $P-T$ evolution.

FIGURE 13 Sketches depicting the timescale of the integrated petrological (a) and $P-T$ (b) evolution of samples EGB-09-45, -47 and -55 . A) The UHT peak was followed by crystallization of melt during slight decompression and slow cooling to form leucosomes in the interval from c. 1050 to c. $800 \mathrm{Ma}$, marked by sector zoned anatectic zircon. B) Neocrystallization of zircon at 550-500 Ma and $>800 \stackrel{\circ}{ } \mathrm{C}$ due to minor fluid influx.

FIGURE 14 A series of sketches to depict the possible tectonic evolution of the EGP between c.1100 and $512 \mathrm{Ma}$ from available geochronological evidence. (a) the Merdith et al. (2017) plate reconstructions in the Robinson projection, drawn using GPlates (Williams, Dietmar Müller, Landgrebe, \& Whittaker, 2012). Red boundaries - destructive plate boundaries, bold black boundaries - transform and constructive plate boundaries. (b) Cross section sketch $x^{\prime}-x$ as illustrated in (a). (c) $P-T$ paths for tectonic blocks labelled 1 (green; Korhonen, Brown, et al., 2013), 2 (blue; this study and Kelsey et al., 2017 with a postulated prograde path) and 3 (red; Halpin, Clarke, et al., 2007; Harley \& Hensen, 1990; Kelly \& Harley, 2004) in column (b). Abbreviations: A - South Australian Craton, AN - Antongil Block, AZ - Azania, B - Borborema Craton, BC - Bastar Craton, C Congo Craton, $\mathrm{Ca}$ - South China Craton, CHR - Crohn Craton, DML - Dronning Maud Land, EA - East Antarctic cratons, EGP - Eastern Ghats Province, EGRT - Eastern Ghats Rayner Terrane, FA - Fisher Arc, $\mathrm{K}$ - Kalahari Craton, IN - Indian cratons, M - Mawson Block, NC - Napier Complex, OGS Oygarden Group/Stilwell Hills, PB - Prydz Belt, SF - San Francisco Craton, Y - Yilgarn Craton.

This article is protected by copyright. All rights reserved. 
TABLE 1 Mineral area proportions for petrological domains in samples EGB-09-45 and -47 (see Figure 3) from Tescan-Integrated-Mineral-Analyser (TIMA) phase maps.

TABLE 2 Calculated bulk compositions for petrological domains in samples EGB-09-45 and -47 (see Figure 3).

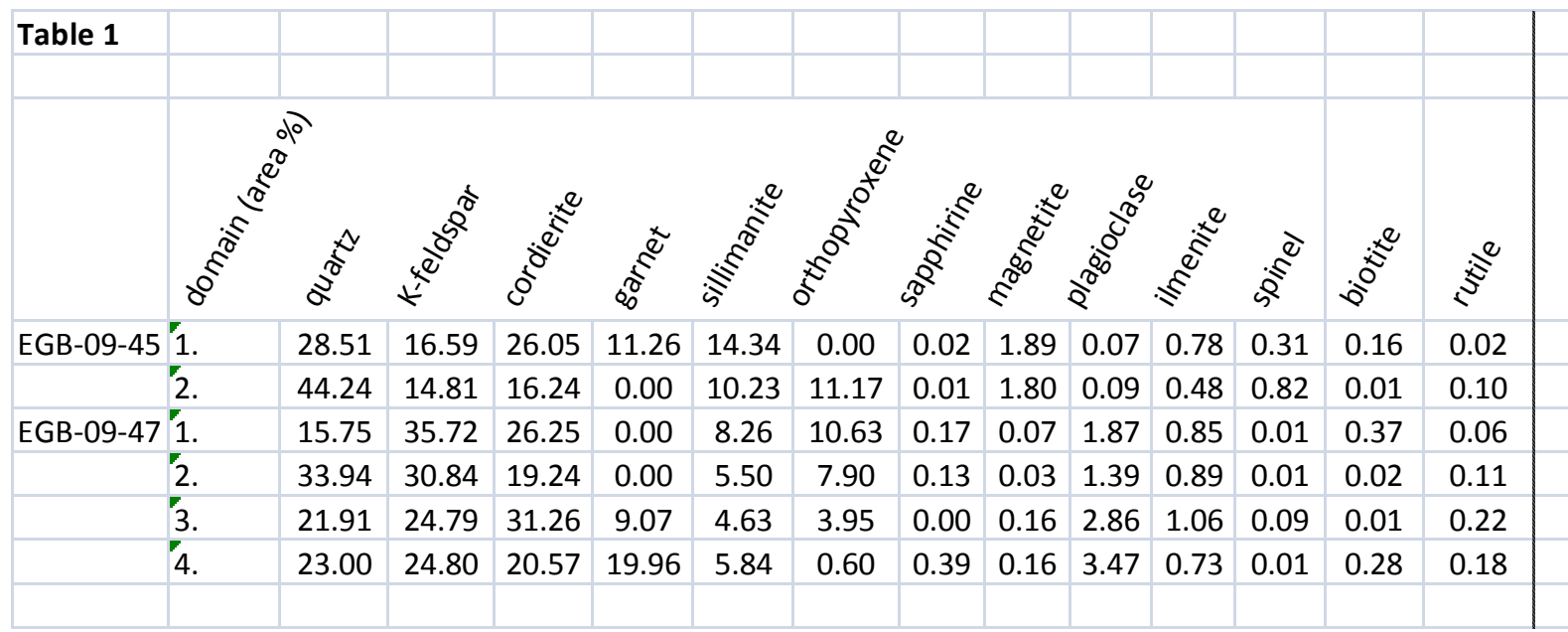

\begin{tabular}{|c|c|c|c|c|c|c|c|c|c|c|c|c|c|}
\hline \multicolumn{14}{|l|}{ Table 2} \\
\hline \multicolumn{14}{|c|}{ do } \\
\hline & $0^{\stackrel{5}{5}}$ & $\underset{2}{0}$ & $i^{2}$ & $\frac{0^{n}}{\nabla^{2}}$ & $0^{\circ}$ & $5^{80}$ & $\otimes^{8}$ & 20 & $\overbrace{}^{2}$ & $\stackrel{2}{ }^{2}$ & 0 & $t^{50}$ & $\sqrt{4}^{5}$ \\
\hline \multirow[t]{2}{*}{ EGB-09-45 } & 1. & 0.04 & 82.29 & 8.67 & 0.08 & 2.06 & 4.31 & 0.72 & 0.20 & 0.41 & 1.22 & 0.32 & 0.58 \\
\hline & 2. & 0.01 & 86.93 & 4.93 & 0.02 & 2.89 & 3.49 & 0.46 & 0.14 & 0.35 & 0.78 & 0.45 & 0.44 \\
\hline \multirow[t]{4}{*}{ EGB-09-47 } & 1. & 0.06 & 77.46 & 9.24 & 0.20 & 5.64 & 3.60 & 2.04 & 0.50 & 1.17 & 0.09 & 0.61 & 0.50 \\
\hline & 2. & 0.02 & 87.54 & 4.84 & 0.11 & 2.92 & 2.06 & 1.22 & 0.30 & 0.95 & 0.05 & 0.59 & 0.49 \\
\hline & 3. & 0.04 & 81.66 & 7.02 & 0.26 & 4.06 & 3.50 & 1.28 & 0.39 & 1.58 & 0.21 & 0.54 & 0.48 \\
\hline & 4. & 0.04 & 82.10 & 7.44 & 0.35 & 3.48 & 3.57 & 1.28 & 0.44 & 1.13 & 0.16 & 0.49 & 0.51 \\
\hline
\end{tabular}

This article is protected by copyright. All rights reserved. 


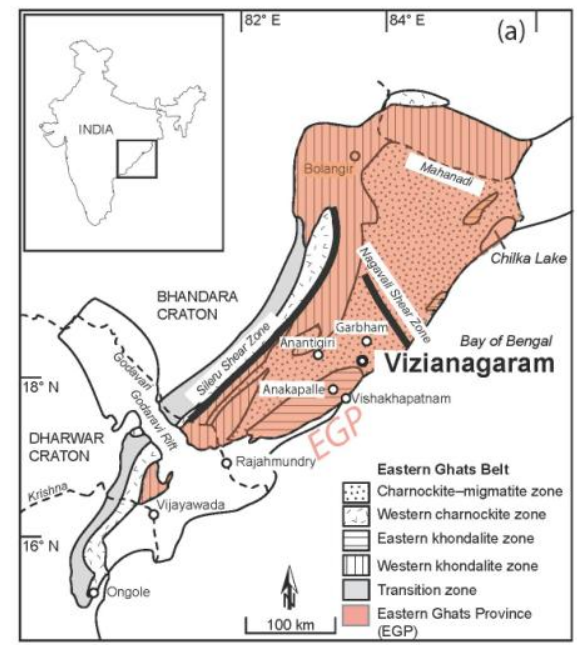

Mitchell et al. (2018) Fig. 1

This article is protected by copyright. All rights reserved. 


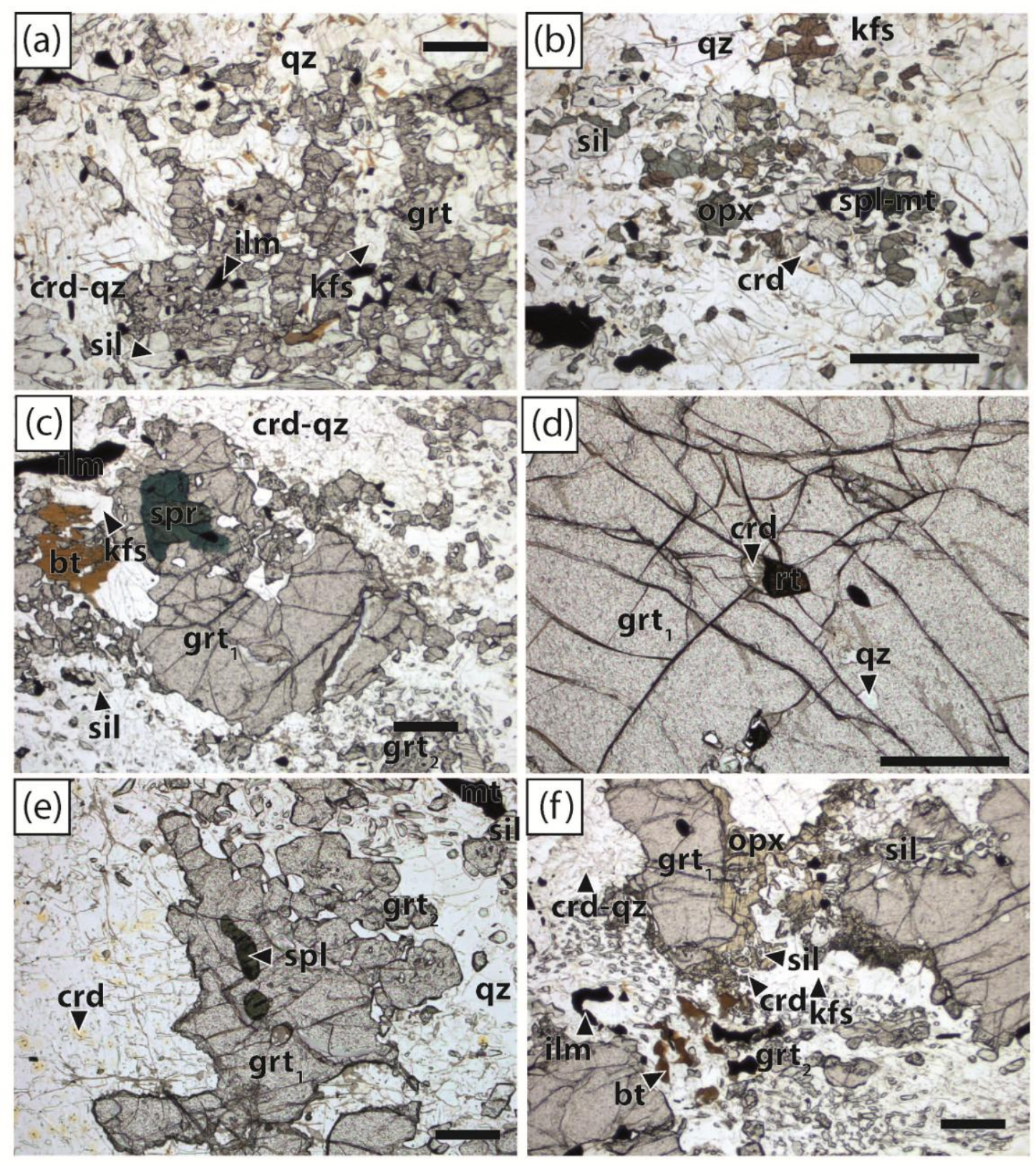

Mitchell et al. (2018) Fig. 2

This article is protected by copyright. All rights reserved. 

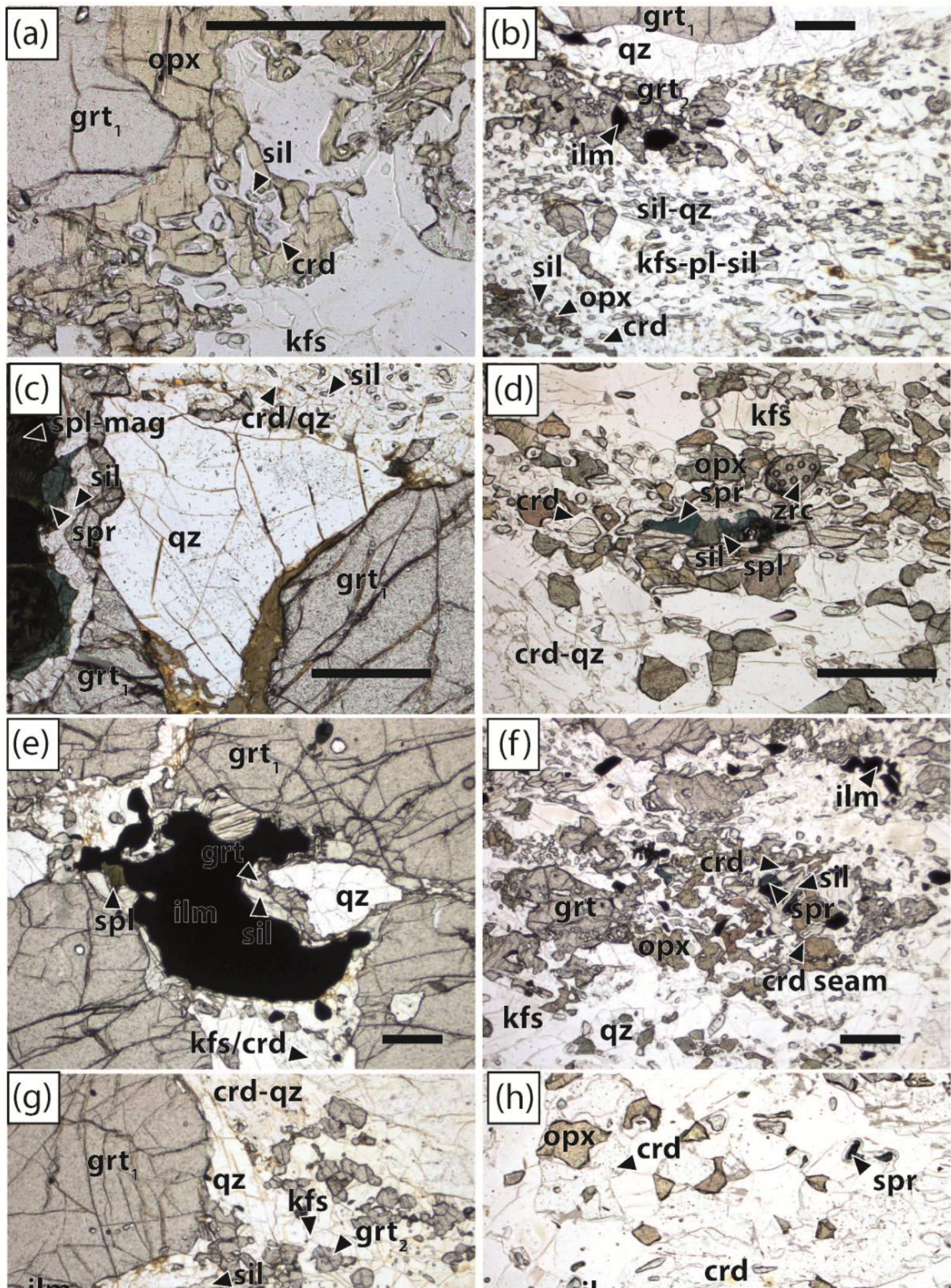

(h) 5 कर opx crd $1, S_{\text {spr }}$.

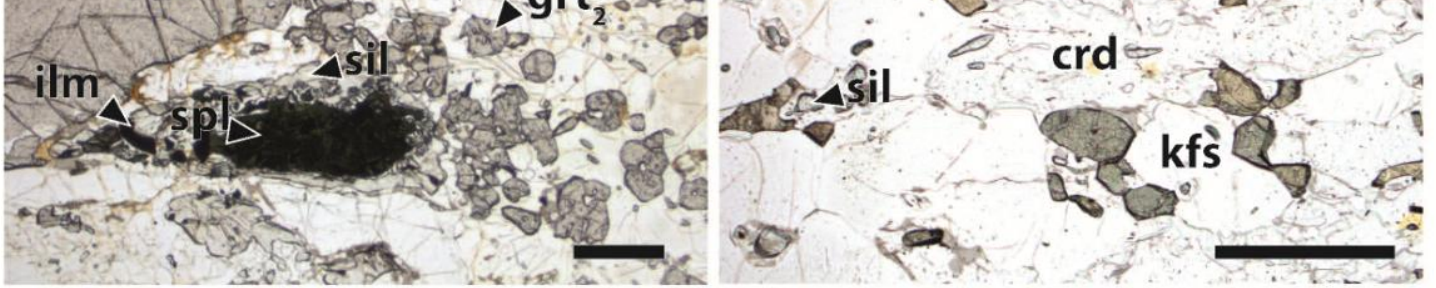

Mitchell et al. (2018) Fig. 3

This article is protected by copyright. All rights reserved. 
(a) EGB-09-45

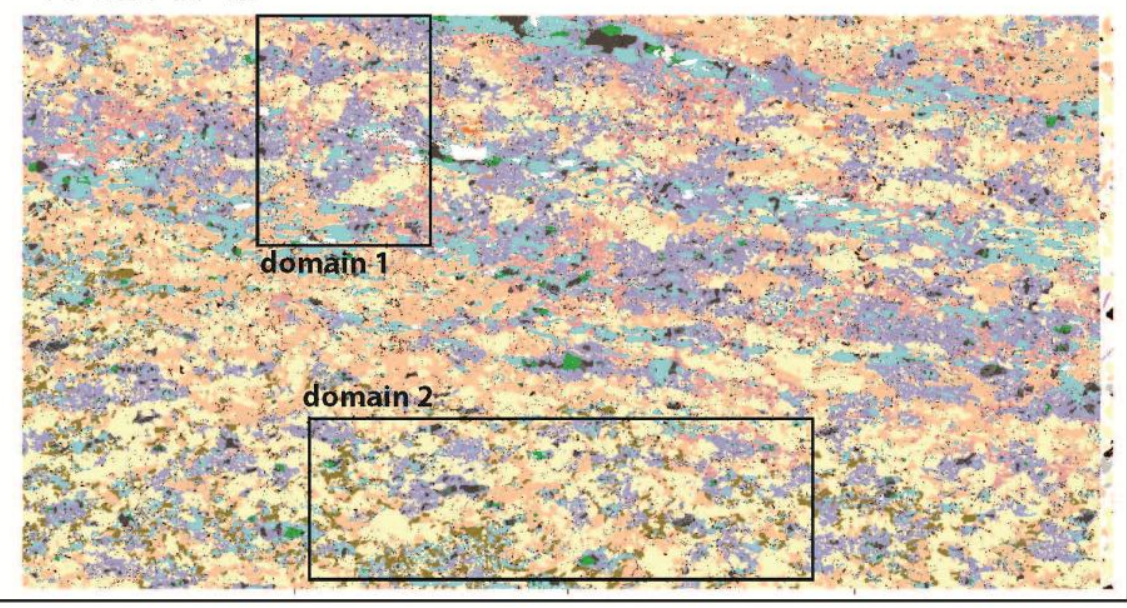

(b) EGB-09-47
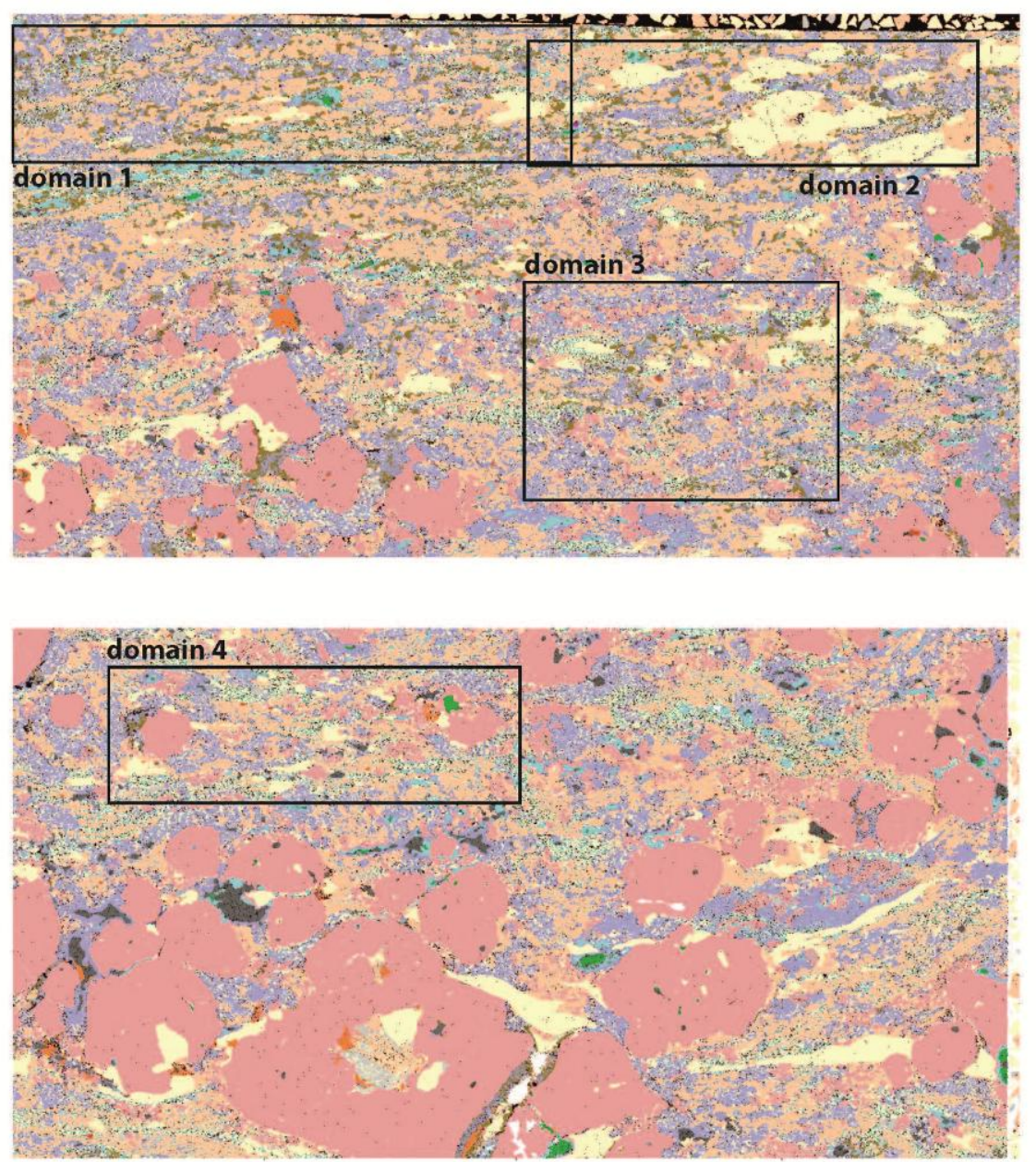

Mitchell et al. (2018) Fig. 4 cordierite quartz

sillimanite

plagioclase

- ilmenite

biotite

hercynite

magnetite/hematite

a sapphirine

orthopyroxene

rutile

muscovite

zircon

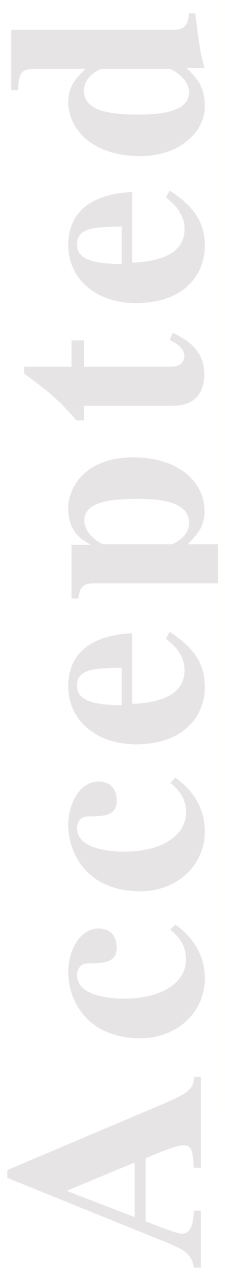

This article is protected by copyright. All rights reserved. 


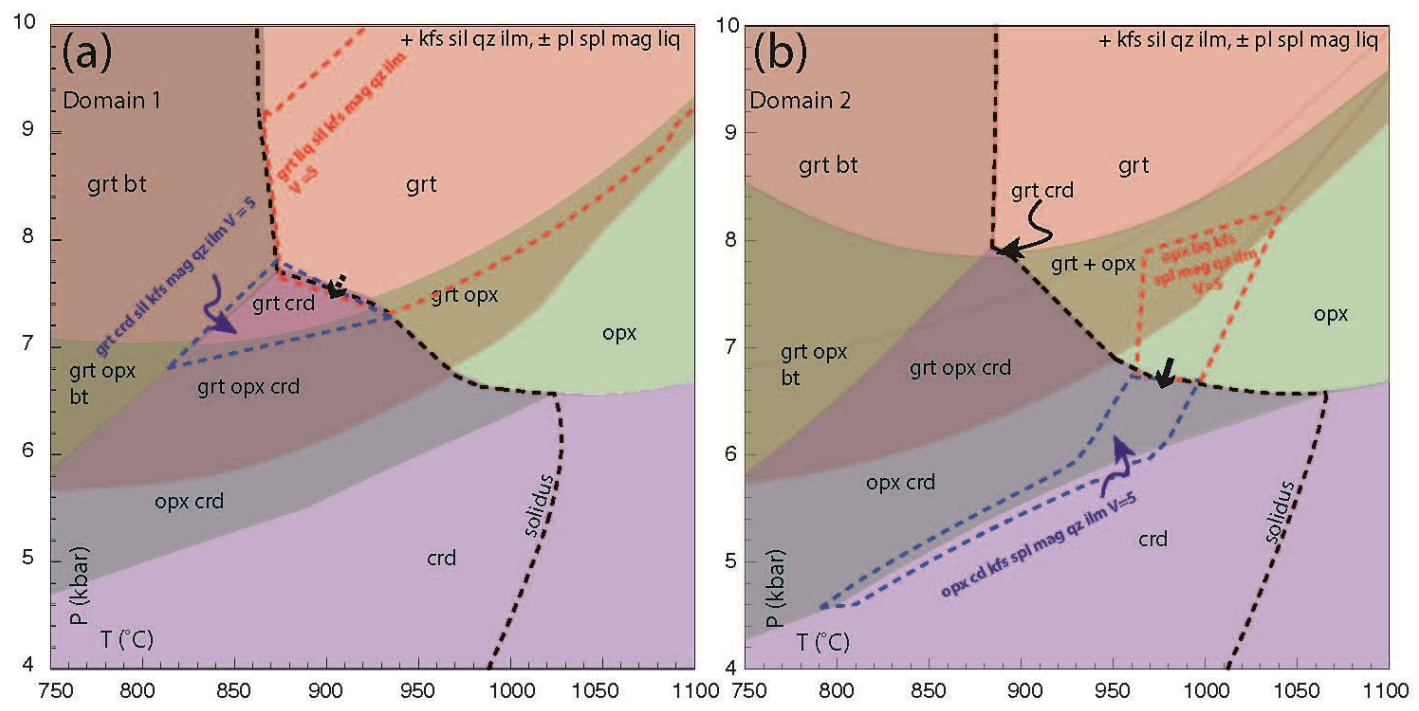

Mitchell et al. (2018) Fig. 5

This article is protected by copyright. All rights reserved. 

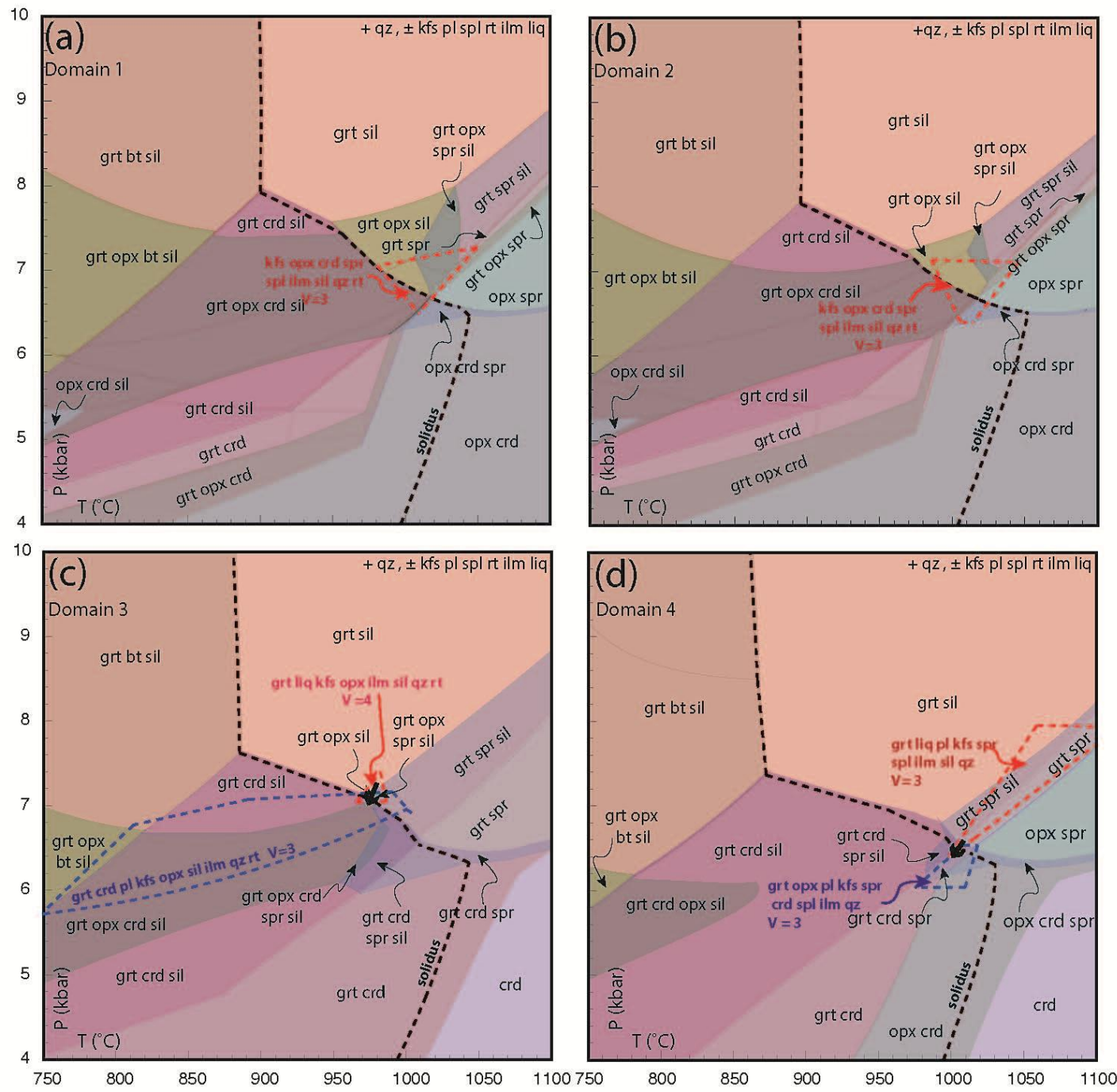

Mitchell et al. (2018) Fig. 6

This article is protected by copyright. All rights reserved. 


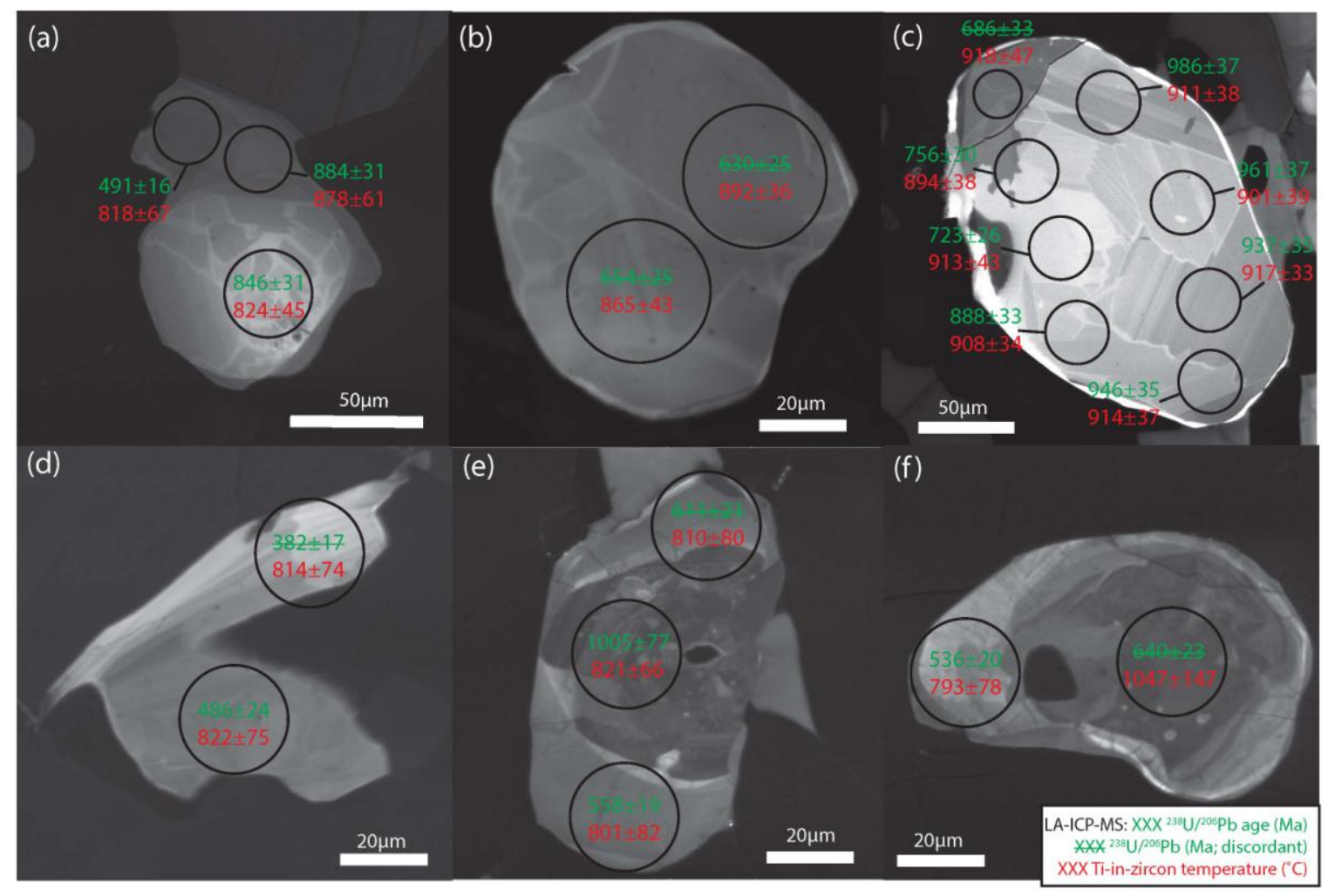

Mitchell et al. (2018) Fig. 7

This article is protected by copyright. All rights reserved. 


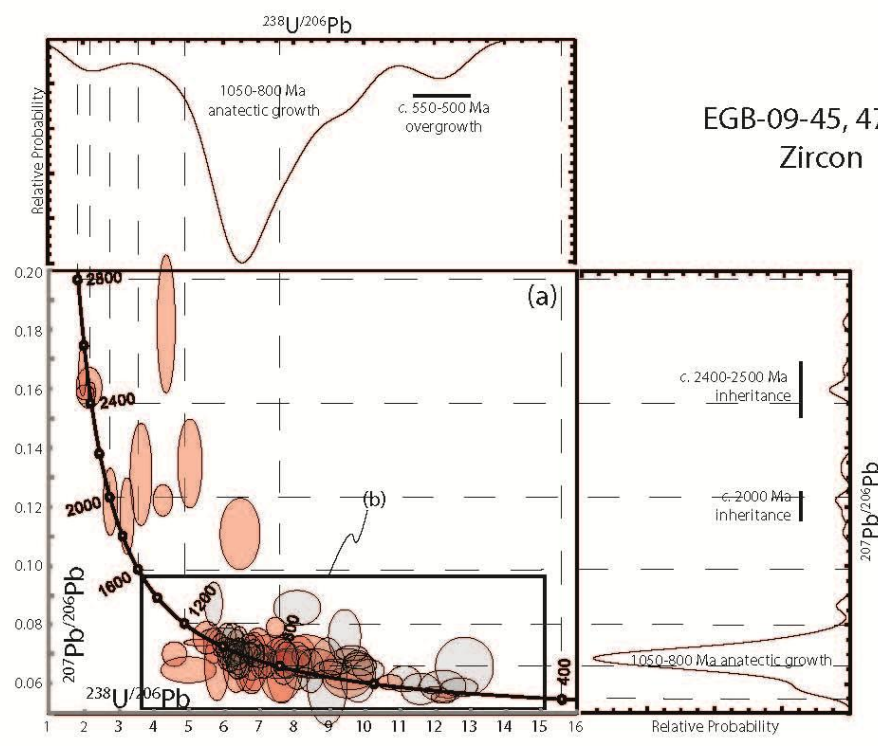

$-45,47,55$

in-situ LA-ICP-MS $\mathrm{n}=32$

in-situ LA-ICP-MS $n=32$
error ellipses are $2 \sigma$

SHRIMP $n=60$

error ellipses are $2 \sigma$
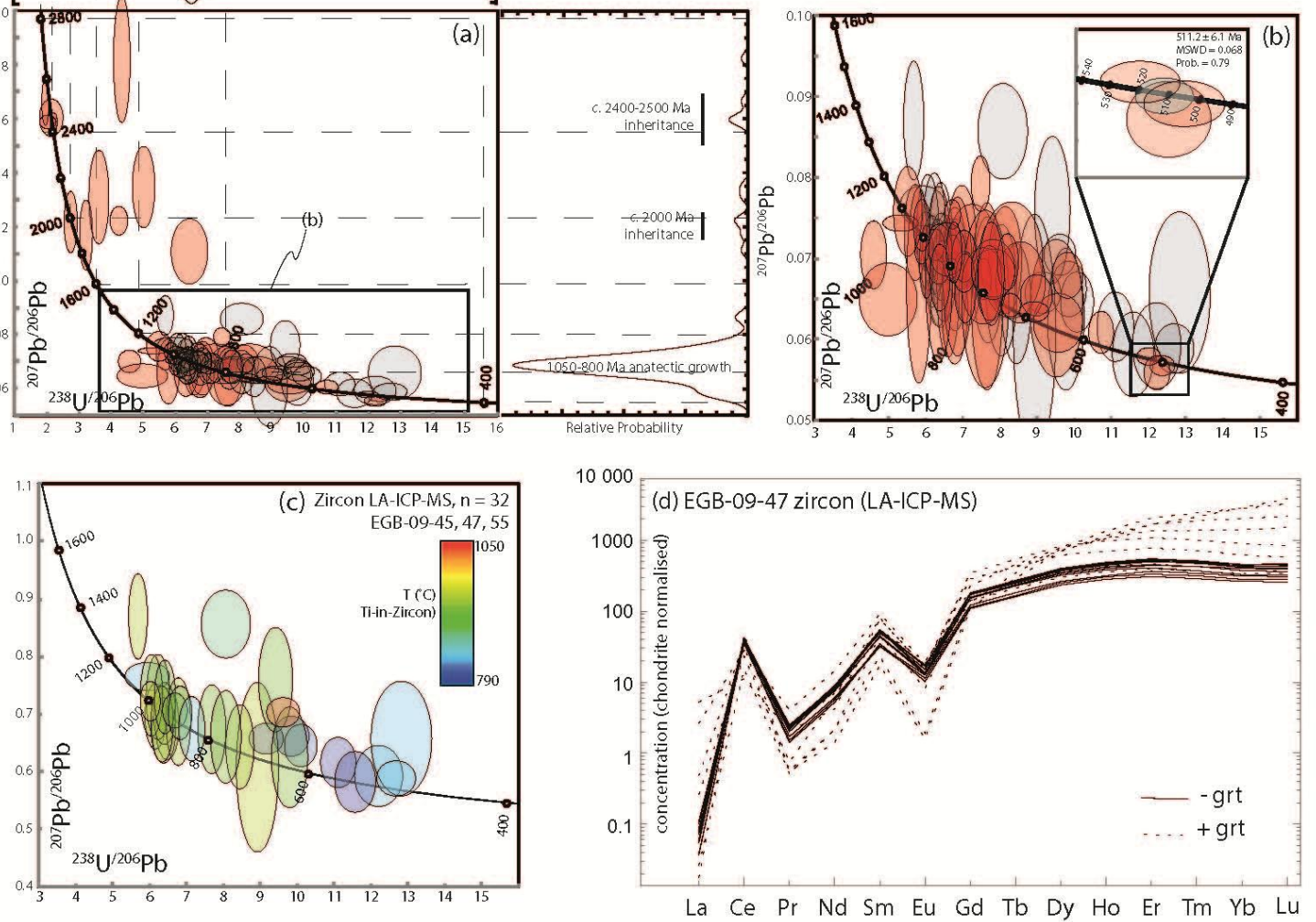

Mitchell et al. (2018) Fig. 8

This article is protected by copyright. All rights reserved. 

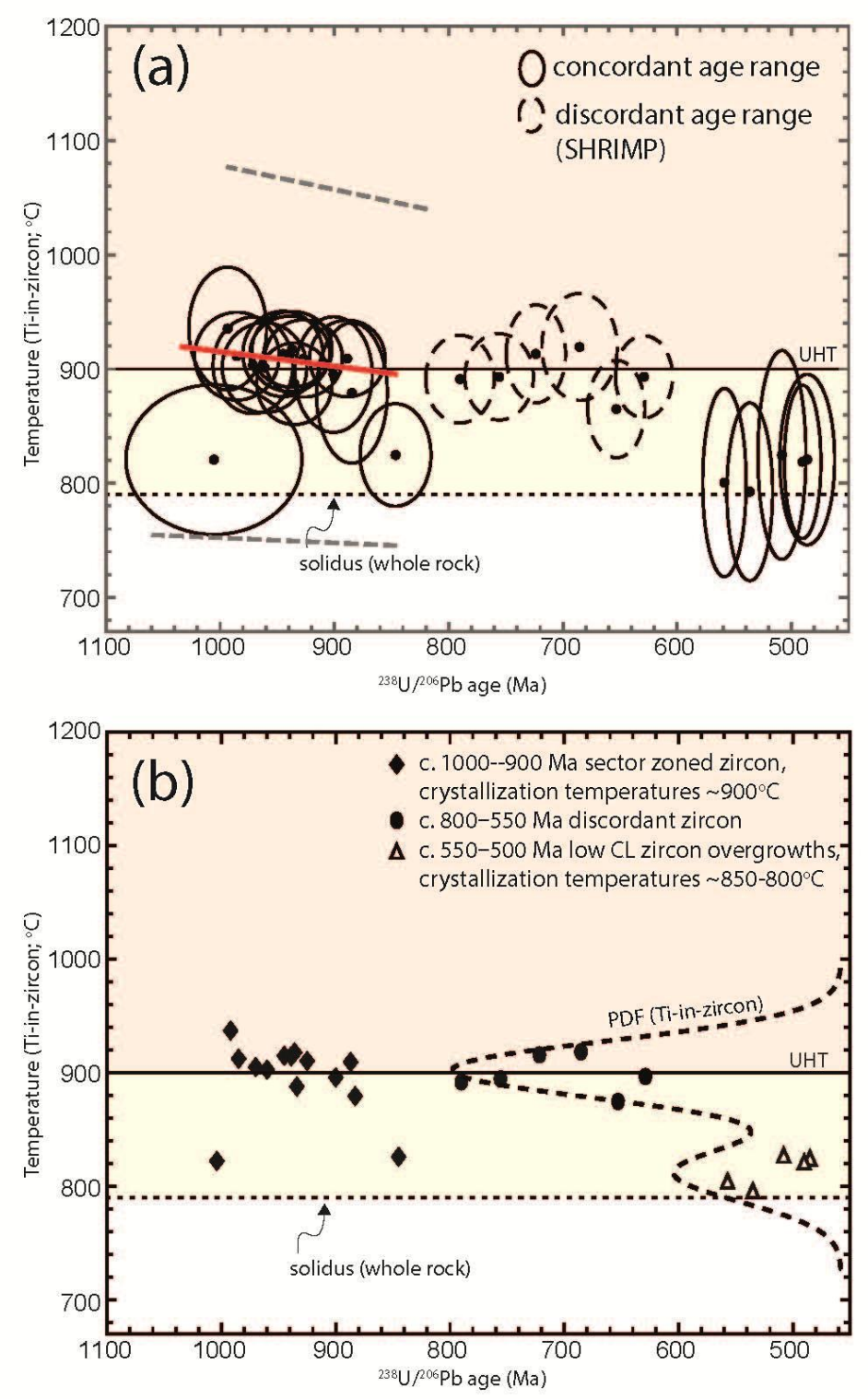

Mitchell et al. (2018) Fig. 9

This article is protected by copyright. All rights reserved. 


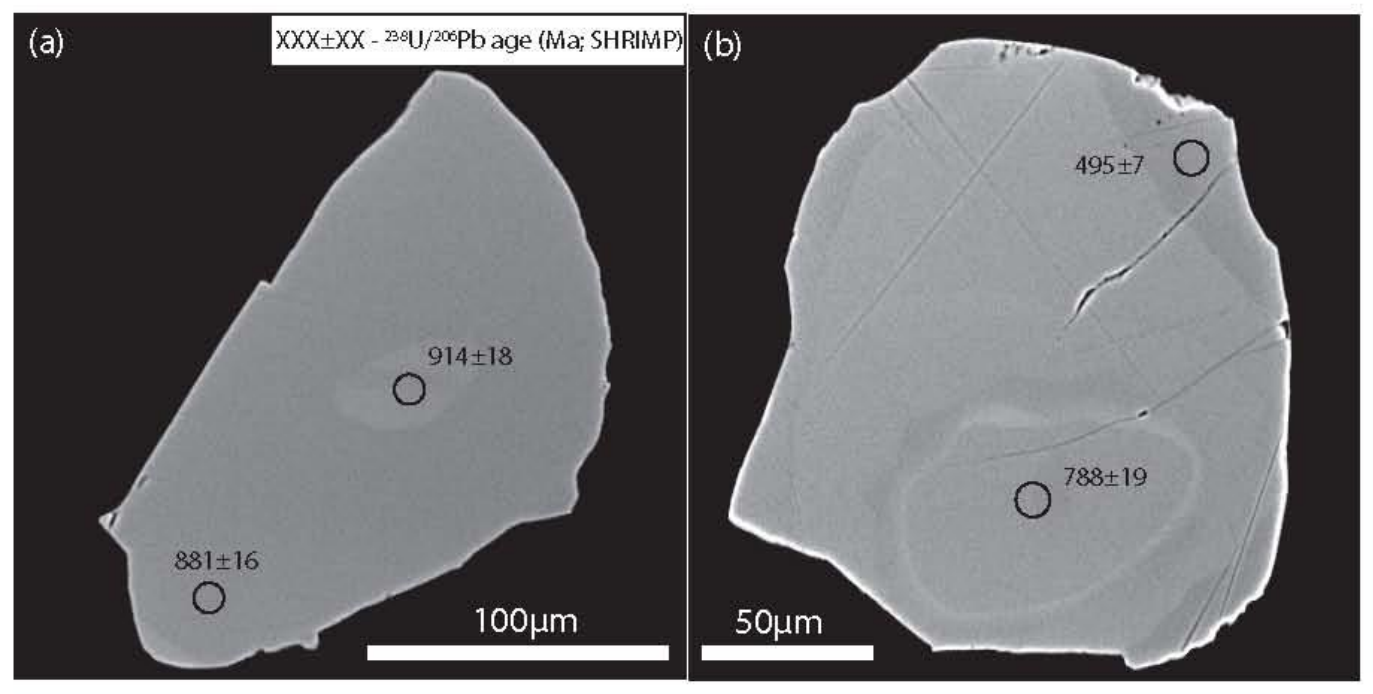

Mitchell et al. (2018) Fig. 10

This article is protected by copyright. All rights reserved. 

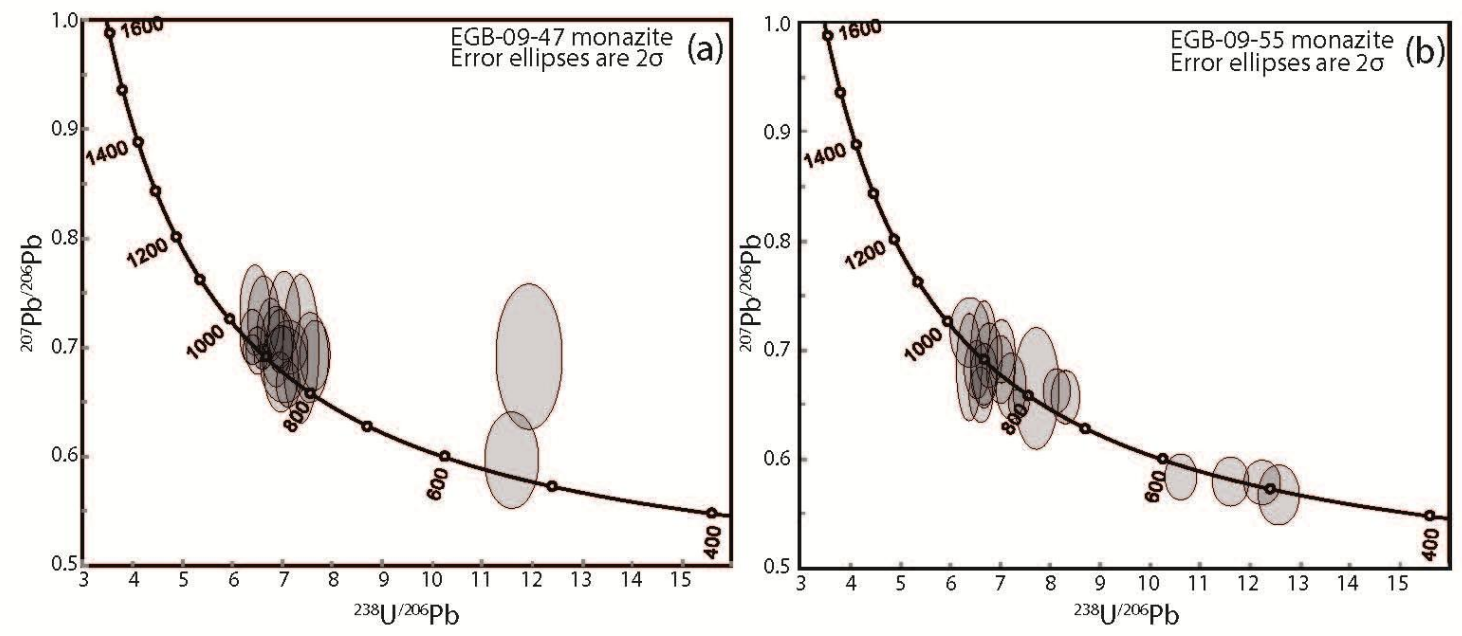

Mitchell et al. (2018) Fig. 11

This article is protected by copyright. All rights reserved. 

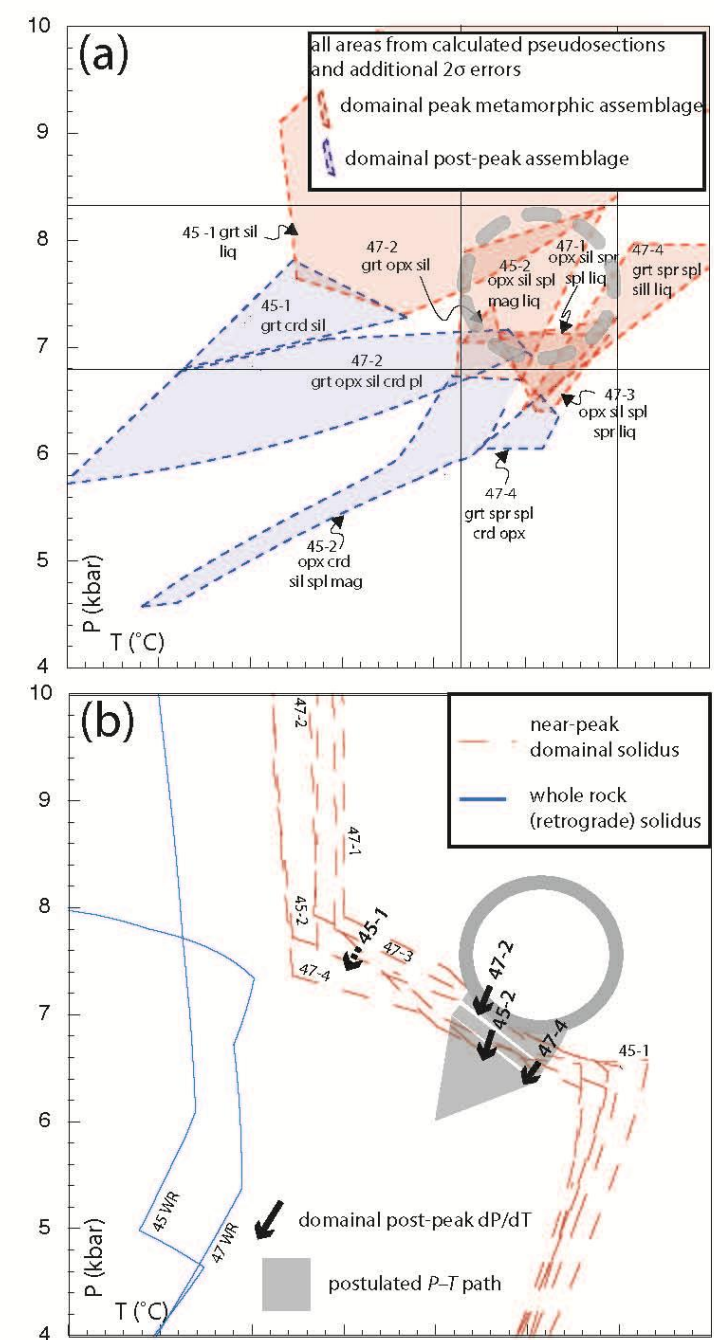

Mitchell et al. (2018) Fig. 12

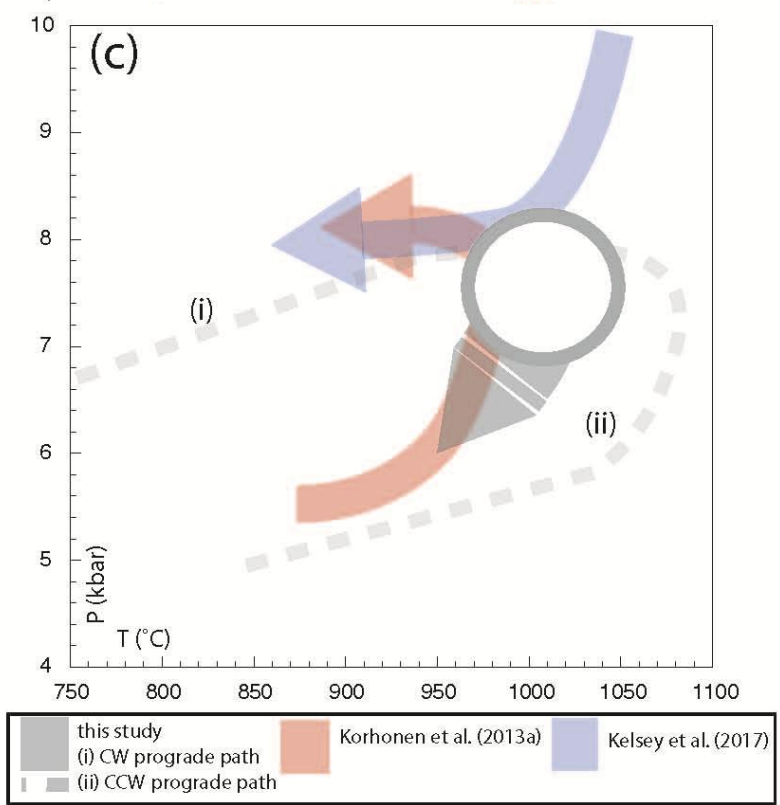

This article is protected by copyright. All rights reserved. 

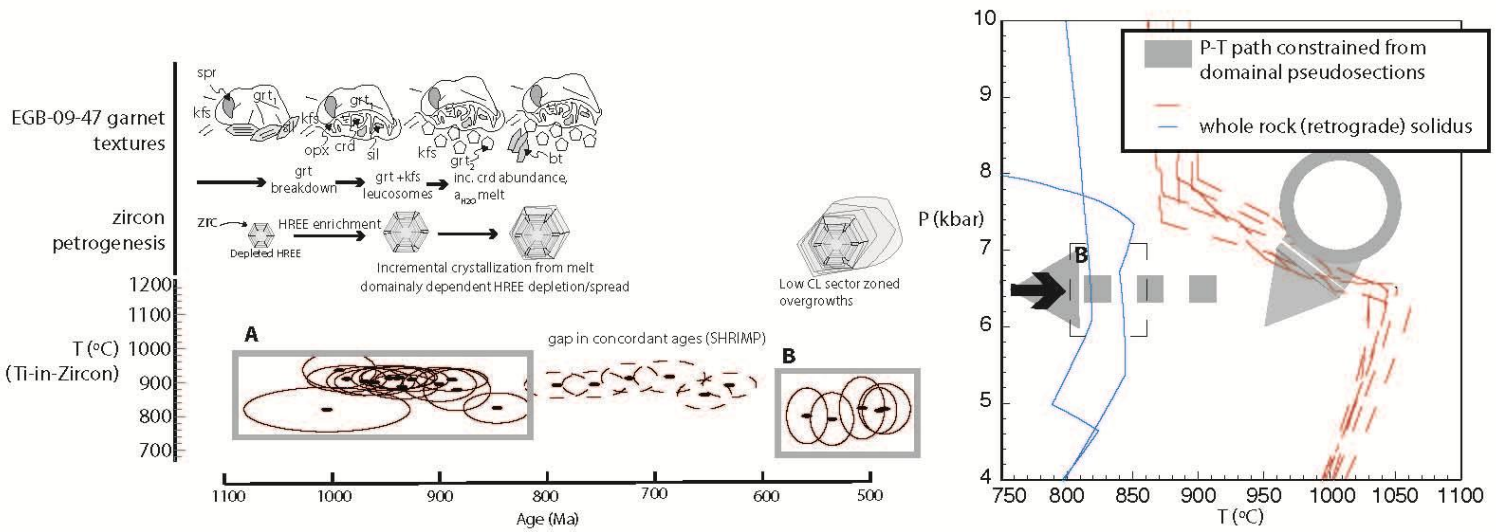

Mitchell et al. (2018) Fig. 13

This article is protected by copyright. All rights reserved. 


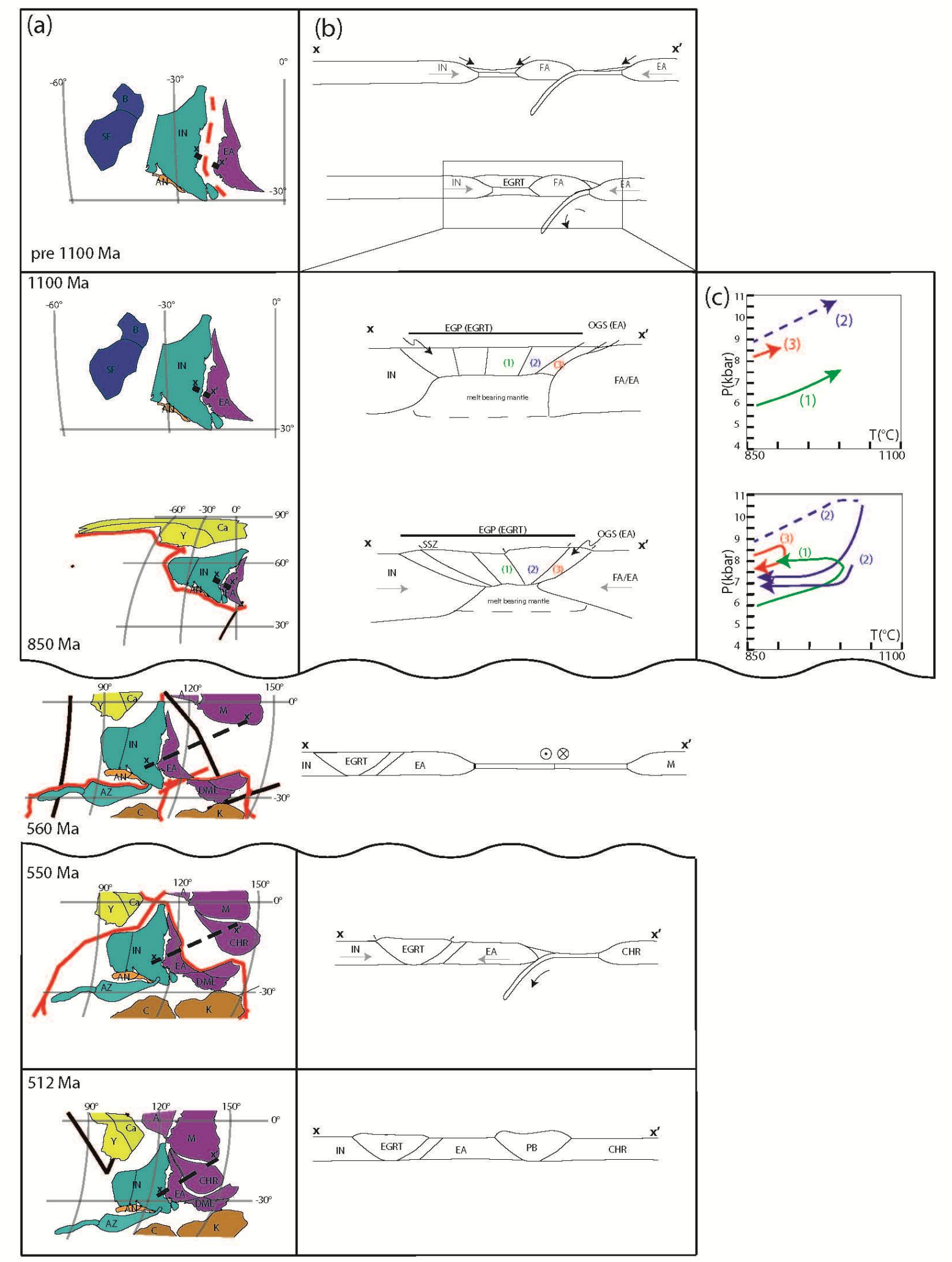

Mitchell et al. (2018) Fig. 14

This article is protected by copyright. All rights reserved. 